\title{
New Treatment Options for Advanced Gastroesophageal Tumours: Mature for the Current Practice?
}

\author{
Hannah Christina Puhr ${ }^{1,2}$, Matthias Preusser 1,2 ${ }^{\mathbb{D}}$, Gerald Prager ${ }^{1,2}$ and Aysegül Ilhan-Mutlu $1,2, *$ (D) \\ 1 Department of Medicine I, Division of Oncology, Medical University of Vienna, Waehringer Guertel 18-20, \\ A-1090 Vienna, Austria; hannah.puhr@meduniwien.ac.at (H.C.P.); matthias.preusser@meduniwien.ac.at (M.P.); \\ gerald.prager@meduniwien.ac.at (G.P.) \\ 2 Comprehensive Cancer Center Vienna-Gastroesophageal Tumors Unit, Waehringer Guertel 18-20, \\ A-1090 Vienna, Austria \\ * Correspondence: aysegul.ilhan@meduniwien.ac.at
}

Received: 28 December 2019; Accepted: 20 January 2020; Published: 28 January 2020

\begin{abstract}
Several clinical trials attempted to identify novel treatment options for advanced gastroesophageal tumours in first, second and further lines. Although results of targeted therapy regimens were mainly disappointing, novel immunotherapy agents showed promising activity, which led to their approval in second and third lines in many countries. This review focuses on the results of recent clinical trials investigating novel agents including targeted therapies, immunotherapy components and chemotherapies and discuss their current impact as well as current approval status on the treatment armamentarium of advanced gastroesophageal tumours.
\end{abstract}

Keywords: gastric cancer; gastroesophageal cancer; targeted therapy; chemotherapy; immunotherapy

\section{Introduction and Background}

Cancer of the upper gastrointestinal (GI) tract is a frequent disease, particularly in Asian countries, and a major contributor to global disease burden and therefore a widely researched topic [1]. However, the overall survival (OS) and prognosis remain poor especially in more advanced stages. Thus, a multidisciplinary approach and new treatment options are essential for patients with cancer of the upper gastrointestinal tract [2].

Since there are major differences concerning aetiology, incidence as well as treatment options, gastroesophageal cancer may be seen as two individual entities including gastric and gastroesophageal junction cancer (adenocarcinoma) as well as oesophageal cancer (squamous cell carcinoma). In spite of this vast diversity, the prognosis of both entities is similar. The 5-year relative survival for oesophageal and gastric cancer is $25.1 \%$ and $31.0 \%$ at locally advanced stages, and $4.8 \%$ and $5.3 \%$ at metastatic stages, respectively $[3,4]$. Seen as these malignant diseases progress very fast, several treatment lines are required to offer these patients the appropriate and evidence-based therapy as their disease advances.

Recently, there have been several clinical phase III and phase II studies to investigate the benefit of different therapy regimens including immunotherapy, targeted therapy and chemotherapy on the overall survival of patients with gastroesophageal tumours in several lines of treatment. Results of some of these trials have a major impact on the clinical practice and, thus, are discussed in this review of new treatment options for patients with metastatic gastroesophageal cancer. 


\section{Gastric and Gastroesophageal Junction Adenocarcinoma}

\subsection{Immunotherapy}

\subsubsection{Third and Further Lines}

The first promising results concerning immunotherapy in advanced and metastatic settings were achieved in the clinical phase III ATTRACTION-2 study (ONO-4538-12), investigating the programmed cell death receptor 1 (PD-1) checkpoint inhibitor nivolumab in an Asian cohort (participating countries: Japan, Taiwan and Korea), and the clinical phase II KEYNOTE-059 study, investigating the programmed cell death receptor 1 inhibitor pembrolizumab in a Western cohort (16 participating countries, mainly non-Asian) $[5,6]$. Although, the patients included into both studies were heavily pre-treated and thus already refractory to at least two treatment regimens, the overall response upon immunotherapy was promising (ATTRACTION-2: median OS 5.26 months in the nivolumab group and 4.14 months in the placebo group; hazard ratio (HR) $0.63,95 \%$ confidence interval (CI) $0.51-0.78 ; p<0.0001$; objective response in the nivolumab group $11.2 \% ; 7.7-1.6$, objective response in the placebo group $0 \% ; 0-2.8$; KEYNOTE-059: objective response rate 15.5\%; 95\% CI: 10.1\%-22.4\%; 23 of 148 patients). Furthermore, exploratory analysis of the ATTRACTION-2 of programmed cell death receptor ligand 1 (PD-L1) expression status showed that the benefit on the overall survival was independent of the programmed cell death receptor ligand 1 status. In the KEYNOTE-059 trial however, the median response duration was $16.3(1.6+$ to $17.3+)$ months and 6.9 (2.4 to $7.0+)$ months in patients with programmed cell death receptor ligand 1-positive and programmed cell death receptor ligand 1-negative tumours, respectively, indicating that the programmed cell death receptor ligand 1 status of the patient is an important prognostic marker for the treatment response [6].

Furthermore, recently published data on the long-term follow up from the KEYNOTE-059 trial demonstrate manageable safety and a superior long-term overall survival (OS of 1 year/2 years was $24.6 \% / 12.5 \%, 52 \% / 32 \%$ and $63.6 \% / 40.1 \%$ in cohorts 1,2 and 3 , respectively) [7], thus suggesting that treatment with pembrolizumab confers sustained responses and disease control in patients with advanced gastric or gastroesophageal junction adenocarcinoma.

In the ATTRACTION-2 study the most common adverse events of nivolumab noted were pruritus, diarrhoea, rash and fatigue and there very relatively few (10\%) grade 3 or 4 treatment-related adverse events. Thus, the safety profile of nivolumab in patients with advanced gastric or gastro-oesophageal junction cancer was manageable and similar to that reported in patients with other advanced solid tumours treated with anti-programmed cell death receptor 1 antibodies. Similar toxicity profiles were observed in the KEYNOTE-059 trial. The most common adverse events of pembrolizumab were hypothyroidism, hyperthyroidism and colitis and only $4.6 \%$ of patients experienced grade 3 or 4 events. Due to the data derived by these studies nivolumab and pembrolizumab were approved as salvage therapies by some Asian authorities (Taiwan, South Korea and Japan) and the FDA, respectively [8-11].

In addition to these key findings another checkpoint inhibitor avelumab in the JAVELINGASTRIC-300 study, was investigated in comparison with physicians' choice of either irinotecan or paclitaxel as chemotherapy, but failed to demonstrate superior overall survival (OS) with single-agent avelumab (median OS 4.6 versus 5.0 months; HR 1.1, 95\% CI 0.9-1.4; $p=0.81$ ) [12]. However, avelumab showed a more manageable safety profile than chemotherapy, thus leading to the assumption that this treatment option may be suitable for fragile patients. Further studies are needed to confirm and pursue this strategy.

\subsubsection{Second Line}

In the KEYNOTE-061 trial pembrolizumab was compared to paclitaxel as a second-line treatment in programmed cell death receptor ligand 1 positive patients, but there was no clinically meaningful survival benefit between the groups (median OS: 9.1 months (95\% CI 6.2-10.7) with pembrolizumab and 8.3 months (7.6-9.0) with paclitaxel; HR 0.82, 95\% CI 0.66-1.03; one-sided $p=0.0421)$ [13]. 
However, a post hoc analysis of this study showed a survival benefit for patients with microsatellite instability (MSI) high (MSI-H) tumours as well as tumours with combined positive score (CPS) $>10$. Thus, surmising that microsatellite instability is a valuable predictive marker for the response to immunotherapy in addition to programmed cell death receptor ligand 1 expression. Consistently, this trial demonstrated a better safety profile of immunotherapy compared to chemotherapy.

Thus, additional trials of pembrolizumab in gastric and gastro-oesophageal cancer after failure of chemotherapy are ongoing and need to evaluate the efficacy of this treatment option in preselected patient subgroups. Furthermore, in the KEYNOTE-061 trial the control group received chemotherapy with paclitaxel, which is not the current standard of care for second line treatment. Hence, further trials are needed to draw comparisons between immunotherapy and current second line treatment options.

\subsubsection{First Line}

Since the results of nivolumab and pembrolizumab in the late line of treatment were promising, these agents are tested in a first line setting in combination with standard chemotherapy regimens in the still ongoing CHECKMATE-649 and the KEYNOTE-062 study, respectively [14,15].

In the open-label, phase 3 CHECKMATE-649 trial the combination of the programmed cell death receptor 1 checkpoint inhibitor nivolumab and the cytotoxic T-lymphocyte-associated protein 4 inhibitor ipilimumab will also be investigated. Thus, the results of this study might bring a major breakthrough in the field of first line combined immunotherapy in metastatic cancer of the upper gastrointestinal tract. Furthermore, avelumab is analysed as a maintenance treatment strategy in the JAVELIN-GASTRIC-100 study.

A recent phase II KEYNOTE-059 study (cohort II and III) demonstrated the anti-tumour activity and moderate toxicity profiles of pembrolizumab as monotherapy and in combination with chemotherapy in a first line setting (objective response rate: $25.8 \%$ (95\% CI 11.9-44.6) and 60.0\% (95\% CI, 38.7-78.9), respectively) [16]. Until then, there had been no evaluation of a potential benefit upon a combination strategy of immunotherapy plus chemotherapy when compared to chemotherapy alone. The median overall survival of patients treated with the combination of chemotherapy plus pembrolizumab was 13.8 months (95\% CI 8.6-not estimable) compared to 20.7 months (95\% CI 9.2-20.7) with pembrolizumab monotherapy [16].

At ASCO Annual Meeting 2019, the first results of the clinical phase III KEYNOTE-062 study were presented, which demonstrated pembrolizumab was non-inferior to chemotherapy alone for overall survival in combined positive score $\geq 1$ tumours. A superior and clinically meaningful benefit by improvement of OS, however, was seen in patients with high programmed cell death receptor ligand 1 expressing tumours of combined positive score $\geq 10$ (median OS 17.4 vs. 10.8 months; HR 0.69, 95\% CI 0.49-0.97), but this was not analysed for statistical significance due to the study's hierarchical design. Surprisingly, the combination of the checkpoint inhibitor with chemotherapy was not superior for OS, neither in combined positive score $\geq 1$ nor in combined positive score $\geq 10$ tumours when compared to chemotherapy alone, but showed a favourable trend for the combination (median OS in patients with CPS $\geq 10$ : with combination immunochemotherapy 12.3 vs. 10.8 months with chemotherapy; HR 0.85, 95\% CI 0.62-1.17; $p=0.158$ ) [15]. As observed in several other immune checkpoint inhibition trials, the rates of serious side effects were lowest among patients treated with pembrolizumab alone. Surprisingly, the patients' reported quality of life data using 2 different assessments (EORTC QLQ-C30 and EORTC QLQ-STO22 scales) did not show any improvement of quality of life in the cohort of patients with pembrolizumab alone against chemotherapy [17].

Although the Kaplan-Meier survival curves insinuate that (combination) immunotherapy even has a worse survival rate in the first few months of administration compared to chemotherapy, the curves then cross each other and (combination) immunotherapy shows promising results in the long-term treatment. These suspenseful results might surmise that special subgroups of patients might have a greater benefit from immunotherapy than others and that the identification of these patients might be a great challenge for further studies. 
In this regard an exploratory analysis of the KEYNOTE-062 study presented at the ESMO Annual Meeting 2019 indicated that patients with microsatellite instability high and combined positive score $\geq 1$ tumours might benefit from pembrolizumab +/- chemotherapy compared to chemotherapy alone (pembrolizumab vs. chemotherapy: median OS not reached vs. 8.5 months; HR 0.29; 95\% CI 0.11-0.81 and pembrolizumab + chemotherapy vs. chemotherapy: Median OS not reached vs. 8.5 months; HR 0.37; 95\% CI 0.14-0.97) [18]. Interestingly, the previous results stating the non-inferiority of pembrolizumab monotherapy against chemotherapy in combined positive score $\geq 1$ patients as well as the superior outcome of pembrolizumab monotherapy against chemotherapy in combined positive score $\geq 10$ patients remain significant, when microsatellite instability high patients are excluded from the cohort, suggesting that the presence of microsatellite instability high patients did not substantially affect the outcome of this clinical trial.

However, despite these promising findings, it is important to await the final results of the KEYNOTE-062 trial before recommending pembrolizumab in a first line setting in order to provide a safe and sufficient treatment option.

\subsection{Targeted Therapies}

\subsubsection{Third and Further Lines}

Apatinib (Rivoceranib), a VEGFR2 tyrosine kinase inhibitor, showed positive results compared to placebo in a Chinese population, leading to its approval by Chinese authorities [19]. The phase III trial ANGEL is currently studying apatinib in a Western cohort, but first results, which were presented at the ESMO Annual Meeting 2019 [20], were disappointing. The overall survival was not significantly improved in the overall population, while a subgroup analysis demonstrated a benefit for patients in $\mathrm{a} \geq 4$ th line setting as well as patients with liver metastasis. Apatinib also seems to have a favourable tolerability profile. However, these findings failed to shift the paradigm of further line therapy strategies in the Western population.

Regorafenib, a tyrosine kinase inhibitor targeting multiple angiogenesis and growth pathways, is currently under investigation in the phase III INTEGRATE-II trial [21]. The final results of these studies are not yet published. Furthermore, the phase Ib REGONIVO trial investigated the combination therapy of regorafenib and nivolumab and showed promising results concerning manageable safety profiles and encouraging anti-tumour activity [22]. Thus, further investigations in a larger cohort are planned.

\subsubsection{Second Line}

In the second line setting, the results of the REGARD and RAINBOW studies, which investigated the effect of ramucirumab, an antibody against VEGFR2, alone (median OS with ramucirumab 5.2 months vs. 3.8 months in the placebo group; HR 0.776, 95\% CI 0.603-0.998; $p=0.047$ ) and in combination with paclitaxel (median OS with paclitaxel and ramucirumab 9.6 months vs. with paclitaxel 7.4 months; HR 0.807, 95\% CI 0.678-0.962; $p=0.017$ ) have to be considered [23,24]. Both studies showed positive results and consequently leading to the incorporation of ramucirumab as a favourable treatment option in second line in European as well as U.S. guidelines [25,26]. Thus, also patients who are not fit for second line chemotherapy might have a benefit, if treated with ramucirumab as a monotherapy. These promising results were affirmed by the "real-life" efficacy data on ramucirumab treatment in the RAMoss study (median OS 8.0 months; 95\% CI 7.09-8.9) [27].

Other promising targeted therapy options did not show a significant benefit in the OS, e.g., the BRIGHTER study which investigated the inhibition of STAT3 with napabucasin [28].

\subsubsection{First Line}

The last decade brought us several studies investigating various targeted therapies in a first line setting. Regrettably, none of the results showed a significant benefit for patients with gastric and 
gastroesophageal junction cancer. However, several studies with negative results are mentionable: EGFR inhibition with cetuximab (EXPAND study) and with panitumumab (REAL-3 study), MET/HGF inhibitors rilotumumab (RILOMET-1) and Onartuzumab (METGastric study) as well as angiogenesis inhibition with bevacizumab (AVAGAST and AVATAR studies) and with ramucirumab (RAINFALL study) [29-35].

The most recent results targeting the microenvironment concerning the MMP-9 inhibitor andecaliximab (phase III GAMMA-1 trial) were presented at the ASCO GI Meeting 2019, but failed to show a clinical benefit. Although the response rates were significantly better in the andecaliximab group than in the placebo group (response rates: $50.5 \%$ vs. $41.1 \%$; complete responses: $8.3 \%$ vs. $4.7 \%$, $p=0.049)$, there was no difference in the median overall survival (12.5 vs. 11.8 months; HR 0.93 ; $p=0.56)$ [36].

A ray of hope on the horizon of targeted therapies in a first line setting is provided by the phase II FAST study, which showed a sufficient inhibition of the tight junction protein claudin 18.2 with the monoclonal antibody zolbetuximab (median OS 8.4 months with chemotherapy regimen EOX vs. 13.2 months with zolbetuximab; HR $0.51,95 \%$ CI $0.36-0.73 ; p=0.0001$ ) [37]. Due to this finding, two large phase III trials investigating zolbetuximab with different chemotherapy backbones, either with CAPOX or FOLFOX, are currently ongoing and results are expected to be published in the next few years.

\subsection{Chemotherapy}

\subsubsection{Third and Further Lines}

The combination of the chemotherapeutic agents trifluridine and tipiracil, which is already well established in colorectal cancer as third and further line treatment, was recently investigated in patients with advanced and metastatic gastric and gastroesophageal junction cancer in the TAGS study [38]. This novel oral cytotoxic chemotherapy has a unique mechanism of action in which Trifluridine is incorporated into DNA, resulting in DNA dysfunction, and tipiracil blocks trifluridine degradation by thymidine phosphorylase, increasing trifluridine bioavailability. Compared to placebo this combination therapy showed an improvement in overall survival (5.7 months in the trifluridine/tipiracil group versus 3.6 months in the placebo group; HR 0.69, 95\% CI 0.56-0.85; $p=0.00058$ ). The common adverse events were haematological side effects, which could be managed with routine procedures including G-CSF support, transfusions or dose reductions. As a rational concern for an oral drug for bioavailability, a post-hoc analysis for patients with gastrectomy was recently demonstrated, where the survival advantage in the trifluridine and tipiracil arm remained significant [39]. Quality of life data also indicates an improvement of cancer-related symptoms within the trifluridine/tipiracil group [40]. Thus, the U. S. Food and Drug Administration (FDA) and European Medicines Agency (EMA) approved this regimen as salvage treatment for patients with metastatic or advanced gastroesophageal adenocarcinoma, whose tumour progressed after 2 treatment regimens [41].

\subsubsection{Second Line}

Besides from targeted therapy agents, a taxane therapy, usually paclitaxel represents a common treatment choice in a second line setting. A large phase III trial (ABSOLUTE trial) showed the noninferiority of weekly nab-paclitaxel to paclitaxel, which is an important finding considering the lower toxic and better pharmacokinetic properties of the albumin-bound agent. This led to the approval of nab-paclitaxel as a second line treatment option in Japan $[42,43]$.

Furthermore, the findings of the COUGAR-02 trial suggest that docetaxel can be recommended as an appropriate second-line treatment for patients who are refractory to treatment with platinum and fluoropyrimidine (median OS with docetaxel 5.2 months versus 3.6 month in the active symptom control group; HR 0.67; 95\% CI 0.49-0.92; $p=0.01$ ) [44]. 
Aside from that, irinotecan might also be a valid second line option as demonstrated in the WJOG 4007 trial (median OS was 9.5 months in the paclitaxel group and 8.4 months in the irinotecan group; HR $1.13,95 \%$ CI $0.86-1.49 ; p=0.38$ ) [45].

\subsubsection{First Line}

There were no approvals of new chemotherapeutic agents in a first line setting in the last few years. However, the chemotherapy regimen FLOT (combination of leucovarin, 5-FU, oxaliplatin and docetaxel) represents a quite novel treatment regimen, which showed promising results in a first line perioperative setting (FLOT4 trial, median OS 50 months (38.33 to not reached) in FLOT group vs. 35 months in standard chemotherapy group; HR $0.77 ; 95 \%$ CI 0.63-0.94) [46]. Thus, this relatively new regimen might also be considered as first line therapy for patients with an excellent performance status in metastatic settings.

However, it is important to consider, that this regimen was investigated in resectable tumours, with no evidence of distant metastases, and currently there is no available data for advanced settings. There is no properly designed phase III trial testing the doublet treatment regimen against a triplet in metastatic tumours [47]. However, retrospective analyses in Spain and Italy suggested that triplet therapy might be associated with a discreet benefit in efficacy at the expense of an increase in toxicity $[48,49]$. A recently published systematic review and meta-analysis also stated that compared with doublet chemotherapy, triplet chemotherapy improved the overall survival in patients with advanced gastric cancer [50]. But a recent Dutch retrospective survey of this chemotherapy regimen used in a first line palliative setting demonstrated no survival benefit in triplet chemotherapy patients compared to doublets [51].

Furthermore, whether gastrectomy in addition to chemotherapy in a first line setting might benefit the overall survival is a highly researched topic. The findings of the REGATTA trial demonstrated that gastrectomy followed by chemotherapy did not show any survival benefit compared with chemotherapy alone in patients with a single non-curable factor, thus concluding that initial gastrectomy cannot be justified as a treatment option [52]. However, the randomized phase III trial RENAISSANCE (AIO-FLOT5) is currently investigating whether oligo-metastatic patients with an excellent performance status have a benefit from gastrectomy with perioperative chemotherapy with the FLOT regimen [53]. Patients without disease progression after 4 cycles are randomized 1:1 to receive additional chemotherapy cycles or surgical resection of primary and metastases followed by subsequent chemotherapy. If this concept proves to be effective, this could potentially lead to a new treatment option for patients with an oligo-metastatic disease and an excellent performance score.

\section{Oesophageal Cancer}

The most recent breakthrough concerning advanced and metastatic oesophageal cancer was the presentation of the findings of the KEYNOTE-181 trial at the ASCO GI Meeting 2019. Patients with oesophageal tumours, adenocarcinomas and squamous cell carcinomas, with a combined positive score of 10 or more, which accounted for about $35 \%$ of the study population, benefited from pembrolizumab in a second line setting when compared to chemotherapy (median OS of 9.3 months with pembrolizumab vs. 6.7 months with chemotherapy; HR $0.69, p=0.0074$ ). The 12-month survival rate in this group was $43 \%$ vs. $20 \%$, respectively. Nevertheless, it did not improve overall survival or progression-free survival in the overall intent-to-treat population, but a trend was observed favouring pembrolizumab in patients with squamous cell carcinoma [54]. These differences favouring pembrolizumab did not meet the study's prespecified statistical boundary of $p \leq 0.0075$. The U. S. Food and Drug Administration approved this treatment in patients with squamous cell carcinoma and a combined positive score $\geq 10$.

Almost simultaneously, first findings of the CHECKMATE-473/ATTRACTION-3 trial were published, that showed a survival benefit in a second line setting in patients with oesophageal squamous cell carcinomas [55]. The median overall survival in patients treated with nivolumab compared to chemotherapy with docetaxel or paclitaxel was improved independent of programmed 
cell death receptor ligand 1 expression (median OS: 10.9 months vs. 8.4 months; HR 0.77, 95\% CI 0.62-0.96; $p=0.019$ ). The most frequent grade 3 or 4 treatment-related adverse events were haematological side effects, anaemia in the nivolumab and leukopenia in the chemotherapy group and the incidence of treatment-related adverse events leading to discontinuation was similar in both groups. However, nivolumab showed a statistically significant overall improvement in quality of life versus chemotherapy [56]. An important fact to mention is that 401 (96\%) of 419 enrolled patients were Asian, which might limit the interpretation of the results for non-Asian patients. However, an analysis in Asian and non-Asian patients showed that the overall survival favoured nivolumab in both subgroups.

Furthermore, the identification of other subgroups might also be important in this entity to improve patient selection for new treatment options. In this study the Kaplan-Meier curves for the overall survival also crossed, so it can be surmised that specific subgroups might have a greater benefit from the immunotherapy and should be investigated in further studies.

In first line setting there are several ongoing trials evaluating the efficacy of immunotherapies, especially the results of the phase III trials KEYNOTE-590 (comparing standard chemotherapy with and without pembrolizumab) and the CHECKMATE-648 (comparing chemotherapy alone, combination with nivolumab and combination with nivolumab and ipilimumab) should bring new insights in the treatment of oesophageal squamous cell carcinoma [57,58].

\section{Her2 Positive Gastroesophageal Tumours}

Her2 positive tumours of the upper gastrointestinal tract are a widely researched topic. Since the approval of the monoclonal antibody trastuzumab against Her2 in 2010 following the TOGA trial, a first effective targeted therapy is available for this subgroup of patients [59]. Unfortunately, all recent studies following this major breakthrough did not show any positive results in any treatment lines.

The inhibition of Her2 was the focus of the LOGIC study using lapatinib (median OS with lapatinib 12.2 and with placebo 10.5 months; HR 0.91, 95\% CI 0.73-1.12) and the JACOB study using a combination treatment of trastuzumuab plus pertuzumab with chemotherapy in a first line setting (median OS 17.5 months in the pertuzumab group and 14.2 months in the control group; HR 0.84, 95\% CI 0.71-1.00; $p=0.057)$ [60,61].

As a second line option after disease progression while administering trastuzumab, T-DM1 was investigated in a large phase III trial, but failed to improve the overall survival while causing a similar amount of adverse events to standard chemotherapy (GATSBY trial; median OS: 7.9 months with trastuzumab emtansine and 8.6 months with taxane treatment; HR 1.15, 95\% CI 0.87-1.51, one-sided $p=0.86$ ) [62]. Another phase III trial, the TyTAN trial, investigated the Her2 inhibitor lapatinib plus paclitaxel versus paclitaxel alone in a second line setting in an Asian population with Her2 positive advanced gastric cancer. Although the addition of lapatinib demonstrated activity in the second-line treatment, it did not significantly improve the overall survival in the intent-to-treat population (11.0 months with lapatinib plus paclitaxel versus 8.9 months with paclitaxel alone; HR 0.84; 95\% CI 0.64-1.11; $p=0.104)$ [63].

Another question that arose with the paradigm shifting results of the TOGA trial, was whether trastuzumab should be administered beyond progression. Results of a phase II study comparing the combination of paclitaxel with beyond progression trastuzumab versus paclitaxel alone in Her2 positive patients, who already received first line antibody/chemotherapy combination therapy, showed that there was no benefit of combination therapy concerning the overall survival (9.95 months with paclitaxel versus 10.2 months in the paclitaxel + trastuzumab arm; HR $=1.23$; 95\% CI 0.75-1.99; $p=0.20$ ) [64]. It is surmised that this effect might be due to the loss of HER2 after first line treatment, since almost $2 / 3$ of patients lost their Her2 positivity, which was evaluated in an additional biopsy at the time of progression under trastuzumab $[64,65]$. However, some new retrospective analyses suggest that although there is no improvement of the OS, patients might still have a clinical benefit from the 
continuation of Trastuzumab beyond first-line progression [66,67]. These results deserve a prospective randomized validation.

The combination of the immunotherapy agent pembrolizumab with the TOGA protocol has recently been investigated in Her2 positive metastatic or advanced gastroesophageal adenocarcinoma patients in a phase II trial. Notably, all patients had a tumour regression ranging from $-4 \%$ to $-100 \%$ (RECIST 1.1 objective response rate was $89 \%$ with 27 partial remissions and 3 complete remissions) and a median overall survival of 27 months, which is significantly higher than in the historical control group of the TOGA trial $[68,69]$. Furthermore, this outcome was programmed cell death receptor ligand 1 independent. These promising findings will be further investigated in the phase III KEYNOTE-811 trial [70].

Furthermore, the mechanisms of primary resistance against anti-Her2-treatment is of high clinical interest. It is surmised that resistant tumours have activated other tyrosine kinase receptors or downstream signalling pathways. To avoid unnecessary toxicity of the therapy with no clinical benefit, it is a crucial task to determine which tumours are resistant before initiating therapy. However, although several genomic alterations are suspected to be clinically useful to predict primary resistance to Trastuzumab in HER2-positive metastatic gastric cancer patients, none of them have yet been included into routine evaluations [71].

\section{Tissue Agnostic Approval and Cancer Genome Atlas}

In the last few years, due to novel drug developments such as immunotherapy or targeted therapy, new strategies to target cancer cells have been introduced to modern oncology practice. In drugs with tissue agnostic approval, the treatment of the cancer cells is based on the mutations that they display, instead of the tissue type in which they appear. This novel strategy led to new treatment options also in gastroesophageal cancer patients.

Recently, advances in technology and high-throughput analysis have also improved our understanding of the genetic background of gastric cancer. To provide a roadmap for patient stratification and trials of targeted therapies and immunotherapies, the Cancer Genome Atlas (TCGA) Research Network has characterized almost 300 primary gastric adenocarcinomas and proposed a new classification of four different tumour subtypes: Epstein-Barr virus positive, microsatellite instability, genomically stable and chromosomal instability [72]. Based on this new classification tissue agnostic approved therapies might be easily applicable in gastric cancer patients.

\subsection{Microsatellite Instability}

In 2017 the U.S. Food and Drug Administration approved pembrolizumab for the treatment of unresectable or metastatic, microsatellite instability high/mismatch repair deficiency solid tumours, which have no satisfactory alternative treatment options after at least one prior treatment regimen [73]. Based on this "tissue agnostic approval", testing of microsatellite instability high/mismatch repair deficiency in tissues of all tumour types might have a therapeutic consequence and should therefore be considered if alternative treatment strategies are not satisfactory.

The clinical and pathological characteristics of microsatellite instability are a widely researched topic in gastric cancer patients. Thus, many studies were conducted to enhance the knowledge on this particular matter and in large part these studies demonstrated an association of high microsatellite instability with age, female gender, distal third of the stomach, intestinal pathology, lower pTNM stage and lower number of infiltrated lymphnodes. It is assumed, that approximately one quarter of all Western gastric cancer cases is microsatellite instability high [74-78]. Distinct genetic features including increased number of tumour infiltrating lymphocytes and programmed cell death receptor ligand 1 positivity is generally associated with this subgroup of gastric tumours [74,78].

In this regard, a post-hoc analysis of the British MAGIC trial, which represents a major breakthrough in the treatment of resectable tumours by demonstrating a survival benefit when treated perioperatively with the chemotherapy combination Epirubicin, Oxaliplatin and Capecitabine, was conducted [79]. 
The tissue samples were re-analysed and results showed, that patients with microsatellite instability high tumours benefited less from chemotherapy than the rest of the population. Thus, it was surmised that other treatment strategies should be considered for this selected patient group [80].

Additionally, the post-hoc investigation of the CLASSIC trial affirmed these results and led to similar conclusions. In this Asian study patients were randomized to adjuvant chemotherapy or surgery alone and the post-hoc analysis also failed to show a survival benefit for microsatellite instability high patients, when treated with post-operative chemotherapy [81].

Furthermore, a recently published meta-analysis of the value of microsatellite instability as a biomarker in gastric cancer suggested it to be a robust prognostic marker that should be adopted as a stratification factor by clinical trials and investigated prospectively [82]. Thus, there currently are several randomized prospective trials with microsatellite instability high patients, treated with surgery only in a resectable setting. These investigations are surmised to clarify, whether we should shift the current treatment paradigm in resectable settings and treat this patient subgroup solely with gastrectomy or with alternative therapies, such as immunotherapy, instead of conventional chemotherapy.

\subsection{Epstein-Barr Virus}

Tumour Epstein-Barr Virus (EBV) positivity is suspected to be a major driver in some cancer entities. In the last few years there has been extensive research on the viral status in gastric cancer patients and Epstein-Barr Virus (EBV) positivity is an emerging marker, which might be introduced in personalized treatment. The positivity rate among patients with upper gastrointestinal cancer is estimated to be around $8 \%-10 \%$ and, unlike in other entities, the distribution of Epstein-Barr Virus-associated gastric carcinoma worldwide is surmised to be approximately even [83]. So far, the precise role of the Epstein-Barr Virus as a prognostic factor is not fully clarified, however, several studies indicate the association of viral positivity with a longer overall survival [84-86]. Additional investigations demonstrate an enhancement of programmed cell death receptor ligand 1 expression in Epstein-Barr Virus-positive gastroesophageal tumours. This association suggests this subgroup might benefit from immunotherapy targeting the programmed cell death receptor ligand 1/programmed cell death receptor 1 axis $[87,88]$.

Emphasizing this assumption, a phase II biomarker trial, conducted on a Epstein-Barr Virus positive cohort, recently showed a $100 \%$ overall response rate when treated with pembrolizumab after one prior treatment line [89]. However, so far large clinical trials to confirm these results are missing and thus, the investigation of Epstein-Barr Virus is not routinely recommended in international guidelines. Nevertheless, many academic hospitals have already implemented testing for Epstein-Barr Virus as a part of routine diagnostics and therefore this marker might play an important role in upcoming studies.

\section{Discussion and Conclusions}

Even though gastroesophageal tumours are a major contributor to global disease burden and therefore a widely researched entity, the OS, especially in advanced and metastatic stages, is still poor $[3,4]$. Due to the localization of the primary tumour symptoms of advanced stages often include tumour-specific symptoms such as dysphagia, dyspepsia, vomiting, early satiety and/or iron deficiency anaemia, additionally to common symptoms of malignant diseases like weight loss and fatigue, thus, adding to the burden of the cancer itself and leading to reduced quality of life [90].

New treatment options are therefore desperately needed to improve the survival as well as the quality of life of this large number of patients worldwide. Especially in second, third and further line settings evidence from recent clinical phase 3 trials have emphasised the importance of multiple lines of therapeutic options $[91,92]$. This review illustrates the variety of studies conducted in the last few years to improve therapeutic strategies in patients with advanced and metastatic cancer of the upper gastrointestinal tract in multiple treatment lines. The Tables 1 and 2 give an overview of recent trials discussed in this review as well as recent and expected approvals of second as well as third and further line therapy strategies in locally advanced and metastatic settings, respectively. 
Table 1. Overview of recent trials discussed in this review.

\begin{tabular}{|c|c|c|c|c|c|c|c|c|}
\hline Name & $\begin{array}{c}\text { Trial Number } \\
\text { (Clinical Trials.gov } \\
\text { Identifier or Other) }\end{array}$ & Tumor Type & $\begin{array}{l}\text { Setting } \\
\text { (Line) }\end{array}$ & Phase & Population & Treatment Arms & Status & $\begin{array}{l}\text { Results (First) } \\
\text { Posted }\end{array}$ \\
\hline ATTRACTION-2 & NCT02267343 & $\begin{array}{l}\text { Gastric + GEJ * } \\
\text { adenocarcinoma }\end{array}$ & $\geq 3$ & III & Asia & Nivolumab/Placebo & $\begin{array}{c}\text { Active, } \\
\text { not recruiting }\end{array}$ & 2 December 2017 \\
\hline KEYNOTE-059 & NCT02335411 & $\begin{array}{c}\text { Gastric + GEJ } \\
\text { adenocarcinoma, } \\
\text { cohort 3: CPS } \geq 1\end{array}$ & $1-\geq 3$ & II & $\begin{array}{l}\text { North and South } \\
\text { America, Asia, } \\
\text { Europe }\end{array}$ & $\begin{array}{c}\text { Cohort 1: 3rd line, } \\
\text { Pembrolizumab } \\
\text { Cohort 2: 1st line, Cisplatin + } \\
\text { 5-FU + Pembrolizumab } \\
\text { Cohort 3: 1st line, } \\
\text { Pembrolizumab }\end{array}$ & $\begin{array}{c}\text { Active, } \\
\text { not recruiting }\end{array}$ & 10 May 2018 \\
\hline JAVELIN-GASTRIC-300 & NCT02625623 & $\begin{array}{c}\text { Gastric + GEJ } \\
\text { adenocarcinoma }\end{array}$ & $\geq 3$ & III & $\begin{array}{l}\text { North and South } \\
\text { America, Asia, } \\
\text { Europe }\end{array}$ & $\begin{array}{l}\text { Avelumab/chemotherapy } \\
\text { (physician's choice) }\end{array}$ & $\begin{array}{l}\text { Active, } \\
\text { not recruiting }\end{array}$ & 1 October 2018 \\
\hline KEYNOTE-061 & NCT02370498 & $\begin{array}{l}\text { Gastric + GEJ } \\
\text { adenocarcinoma }\end{array}$ & 2 & III & $\begin{array}{l}\text { North and South } \\
\text { America, Asia, } \\
\text { Europe }\end{array}$ & Pembrolizumab/Paclitaxel & $\begin{array}{l}\text { Active, } \\
\text { not recruiting }\end{array}$ & 20 November 2018 \\
\hline CHECKMATE-649 & NCT02872116 & $\begin{array}{l}\text { Gastric + GEJ } \\
\text { adenocarcinoma }\end{array}$ & 1 & III & Unknown & $\begin{array}{c}\text { Cohort 1: Ipilimumab + } \\
\text { Nivolumab Cohort 2: } \\
\text { Nivolumab + Chemotherapy } \\
\text { Cohort 3: } \\
\text { Chemotherapy } \\
\text { (investigator's choice) }\end{array}$ & $\begin{array}{c}\text { Active, } \\
\text { not recruiting }\end{array}$ & Estimated May 2021 \\
\hline KEYNOTE-062 & NCT02494583 & $\begin{array}{c}\text { Gastric + GEJ } \\
\text { adenocarcinoma, } \\
\text { CPS } \geq 1 \\
\text { HER2-negative }\end{array}$ & 1 & III & $\begin{array}{l}\text { North and South } \\
\text { America, Asia, } \\
\text { Europe }\end{array}$ & $\begin{array}{l}\text { Cohort 1: Pembrolizumab } \\
\text { Cohort 2: Pembrolizumab + } \\
\text { Cisplatin }+ \\
\text { 5-FU/Capecitabine } \\
\text { Cohort 3: Placebo + Cisplatin } \\
\text { + 5-FU/Capecitabine }\end{array}$ & $\begin{array}{c}\text { Active, } \\
\text { not recruiting }\end{array}$ & 1 June 2019 \\
\hline JAVELIN-GASTRIC-100 & NCT02625610 & $\begin{array}{l}\text { Gastric + GEJ } \\
\text { adenocarcinoma, } \\
\text { HER2-negative }\end{array}$ & 1 & III & $\begin{array}{l}\text { North America, } \\
\text { Asia, Europe, } \\
\text { Australia }\end{array}$ & $\begin{array}{c}\text { Avelumab } \\
\text { maintenance/chemotherapy }\end{array}$ & $\begin{array}{l}\text { Active, } \\
\text { not recruiting }\end{array}$ & $\begin{array}{c}\text { Estimated } \\
\text { November } 2019\end{array}$ \\
\hline ANGEL & NCT03042611 & $\begin{array}{c}\text { Gastric + GEJ } \\
\text { adenocarcinoma }\end{array}$ & $\geq 3$ & III & $\begin{array}{l}\text { North America, } \\
\text { Asia, Europe }\end{array}$ & Apatinib/Placebo & $\begin{array}{l}\text { Active, not } \\
\text { recruiting }\end{array}$ & 29 September 2019 \\
\hline
\end{tabular}


Table 1. Cont

\begin{tabular}{|c|c|c|c|c|c|c|c|c|}
\hline Name & $\begin{array}{c}\text { Trial Number } \\
\text { (ClinicalTrials.gov } \\
\text { Identifier or Other) }\end{array}$ & Tumor Type & $\begin{array}{l}\text { Setting } \\
\text { (Line) }\end{array}$ & Phase & Population & Treatment Arms & Status & $\begin{array}{l}\text { Results (First) } \\
\text { Posted }\end{array}$ \\
\hline INTEGRATE-2 & NCT02773524 & $\begin{array}{c}\text { Gastric + GEJ } \\
\text { adenocarcinoma or } \\
\text { undifferentiated } \\
\text { carcinoma }\end{array}$ & $\geq 3$ & III & $\begin{array}{l}\text { North America, } \\
\text { Asia, Australia }\end{array}$ & Regorafenib/Placebo & Recruiting & Estimated July 2020 \\
\hline REGONIVO & NCT03406871 & $\begin{array}{l}\text { Gastric, colorectal } \\
\text { or hepatocellular } \\
\text { cancer }\end{array}$ & $\geq 2$ & $\mathrm{Ib}$ & Asia & Regorafenib + Nivolumab & $\begin{array}{c}\text { Active, } \\
\text { not recruiting }\end{array}$ & 2 July 2019 \\
\hline REGARD & NCT00917384 & $\begin{array}{c}\text { Gastric + GEJ } \\
\text { adenocarcinoma }\end{array}$ & 2 & III & $\begin{array}{l}\text { North and South } \\
\text { America, Asia, } \\
\text { Europe, Australia }\end{array}$ & Ramucirumab/Placebo & Completed & 4 January 2014 \\
\hline RAINBOW & NCT01170663 & $\begin{array}{c}\text { Gastric + GEJ } \\
\text { adenocarcinoma }\end{array}$ & 2 & III & $\begin{array}{l}\text { North and South } \\
\text { America, Europe, } \\
\text { Asia, Australia }\end{array}$ & $\begin{array}{c}\text { Paclitaxel }+ \\
\text { Ramucirumab/Paclitaxel }+ \\
\text { Placebo }\end{array}$ & Completed & 1 October 2014 \\
\hline BRIGHTER & NCT02178956 & $\begin{array}{c}\text { Gastric + GEJ } \\
\text { adenocarcinoma }\end{array}$ & 2 & III & $\begin{array}{l}\text { North America, } \\
\text { Asia, Europe, } \\
\text { Australia }\end{array}$ & $\begin{array}{c}\text { Napabucasin }+ \\
\text { Paclitaxel/Placebo + } \\
\text { Paclitaxel }\end{array}$ & Completed & 20 May 2018 \\
\hline EXPAND & $\begin{array}{c}\text { EudraCT: } \\
\text { 2007-004219-75 }\end{array}$ & $\begin{array}{c}\text { Gastric + GEJ } \\
\text { adenocarcinoma }\end{array}$ & 1 & III & Europe & $\begin{array}{c}\text { Standard chemotherapy + } \\
\text { Cetuximab/standard } \\
\text { chemotherapy (investigator's } \\
\text { choice) }\end{array}$ & Completed & 15 April 2013 \\
\hline REAL-3 & NCT00824785 & $\begin{array}{l}\text { Oesophageal + } \\
\text { gastric + GEJ } \\
\text { adenocarcinoma or } \\
\text { undifferentiated } \\
\text { carcinoma }\end{array}$ & 1 & III & Europe & $\begin{array}{c}\text { Epirubicin + Oxaliplatin + } \\
\text { Capecitabine + } \\
\text { Panitumumab/Epirubicin + } \\
\text { Oxaliplatin + Capecitabine }\end{array}$ & $\begin{array}{l}\text { Terminated } \\
\text { (Lack of } \\
\text { efficacy) }\end{array}$ & June, 2013 \\
\hline RILOMET-1 & NCT01697072 & $\begin{array}{l}\text { Gastric + GEJ } \\
\text { adenocarcinoma, } \\
\text { MET-positive }\end{array}$ & 1 & III & $\begin{array}{c}\text { North and South } \\
\text { America, Europe, } \\
\text { Asia }\end{array}$ & $\begin{array}{c}\text { Epirubicin + Cisplatin + } \\
\text { Capecitabine }+ \\
\text { Rilotumumab/Epirubicin }+ \\
\text { Cisplatin + Capecitabine + } \\
\text { Placebo }\end{array}$ & Terminated & November, 2017 \\
\hline
\end{tabular}


Table 1. Cont

\begin{tabular}{|c|c|c|c|c|c|c|c|c|}
\hline Name & $\begin{array}{c}\text { Trial Number } \\
\text { (ClinicalTrials.gov } \\
\text { Identifier or Other) }\end{array}$ & Tumor Type & $\begin{array}{l}\text { Setting } \\
\text { (Line) }\end{array}$ & Phase & Population & Treatment Arms & Status & $\begin{array}{l}\text { Results (First) } \\
\text { Posted }\end{array}$ \\
\hline METGastric & NCT01662869 & $\begin{array}{l}\text { Gastric + GEJ } \\
\text { adenocarcinoma, } \\
\text { HER2-negative, } \\
\text { MET-positive }\end{array}$ & 1 & III & $\begin{array}{l}\text { North America, } \\
\text { Europe, Asia }\end{array}$ & $\begin{array}{c}\text { 5-FU + Folinic acid + } \\
\text { Oxaliplatin + } \\
\text { Onartuzumab/5-FU + Folinic } \\
\text { acid + Oxaliplatin + Placebo }\end{array}$ & Completed & 1 May 2017 \\
\hline AVAGAST & NCT00548548 & $\begin{array}{c}\text { Gastric + GEJ } \\
\text { adenocarcinoma }\end{array}$ & 1 & III & $\begin{array}{l}\text { North America, } \\
\text { Europe, Asia }\end{array}$ & $\begin{array}{c}\text { Cisplatin }+5 \text {-FU or } \\
\text { Capecitabine }+ \\
\text { Bevacizumab/Cisplatin }+ \\
\text { 5-FU or Capecitabine }+ \\
\text { Placebo }\end{array}$ & Completed & 22 September 2016 \\
\hline AVATAR & NCT00887822 & $\begin{array}{c}\text { Gastric + GEJ } \\
\text { adenocarcinoma }\end{array}$ & 1 & III & Asia & $\begin{array}{c}\text { Cisplatin }+5 \text {-FU or } \\
\text { Capecitabine }+ \\
\text { Bevacizumab/Cisplatin }+ \\
\text { 5-FU or Capecitabine }+ \\
\text { Placebo }\end{array}$ & Completed & 21 February 2014 \\
\hline RAINFALL & NCT02314117 & $\begin{array}{c}\text { Gastric + GEJ } \\
\text { adenocarcinoma, } \\
\text { HER2-negative }\end{array}$ & 1 & III & $\begin{array}{c}\text { North and South } \\
\text { America, Europe, } \\
\text { Asia }\end{array}$ & $\begin{array}{c}\text { Cisplatin + 5-FU or } \\
\text { Capecitabine }+ \\
\text { Ramucirumab/Cisplatin }+ \\
\text { 5-FU or Capecitabine + } \\
\text { Placebo }\end{array}$ & $\begin{array}{l}\text { Active, not } \\
\text { recruiting }\end{array}$ & 1 March 2019 \\
\hline GAMMA-1 & NCT02545504 & $\begin{array}{c}\text { Gastric + GEJ } \\
\text { adenocarcinoma, } \\
\text { HER2-negative }\end{array}$ & 1 & III & $\begin{array}{l}\text { North America, } \\
\text { Europe, Australia }\end{array}$ & $\begin{array}{c}\text { Leucovorin + 5-FU + } \\
\text { Oxaliplatin + } \\
\text { Andecaliximab/Leucovorin + } \\
\text { 5-FU + Oxaliplatin }\end{array}$ & Completed & 29 January 2019 \\
\hline FAST & NCT01630083 & $\begin{array}{l}\text { Oesophageal + } \\
\text { gastric + GEJ } \\
\text { adenocarcinoma, } \\
\text { CLDN18.2 } \\
\text { expression }\end{array}$ & 1 & II & Europe, Asia & $\begin{array}{c}\text { Epirubicin + Oxaliplatin + } \\
\text { Capecitabine + } \\
\text { IMAB362/Epirubicin + } \\
\text { Oxaliplatin + Capecitabine }\end{array}$ & Completed & 11 October 2016 \\
\hline TAGS & NCT02500043 & $\begin{array}{c}\text { Gastric + GEJ } \\
\text { adenocarcinoma }\end{array}$ & 3 & III & $\begin{array}{l}\text { North America, } \\
\text { Europe, Asia }\end{array}$ & $\begin{array}{c}\text { Trifluridine }+ \\
\text { Tipiracil/Placebo }\end{array}$ & Completed & 21 October 2018 \\
\hline ABSOLUTE & JapicCTI-132059 & $\begin{array}{c}\text { Gastric } \\
\text { adenocarcinoma }\end{array}$ & 2 & III & Asia & Paclitaxel/Nab-Paclitaxel & Completed & April, 2017 \\
\hline
\end{tabular}


Table 1. Cont

\begin{tabular}{|c|c|c|c|c|c|c|c|c|}
\hline Name & $\begin{array}{c}\text { Trial Number } \\
\text { (ClinicalTrials.gov } \\
\text { Identifier or Other) }\end{array}$ & Tumor Type & $\begin{array}{l}\text { Setting } \\
\text { (Line) }\end{array}$ & Phase & Population & Treatment Arms & Status & $\begin{array}{l}\text { Results (First) } \\
\text { Posted }\end{array}$ \\
\hline WJOG 4007 & UMIN000001252 & Gastric cancer & 2 & III & Asia & Paclitaxel/Irinotecan & Completed & December, 2013 \\
\hline COUGAR-02 & ISRCTN13366390 & $\begin{array}{c}\text { Gastric + GEJ + } \\
\text { oesophageal } \\
\text { adenocarcinoma }\end{array}$ & 2 & III & Europe & $\begin{array}{c}\text { Docetaxel/active symptom } \\
\text { control }\end{array}$ & Completed & 15 Janurary 2014 \\
\hline FLOT4 & NCT01216644 & $\begin{array}{c}\text { Gastric + GEJ } \\
\text { adenocarcinoma, } \\
\text { locally advanced } \\
(>\mathrm{T} 1) \text { and/or nodal } \\
\text { positive }(\mathrm{N}+)\end{array}$ & 1 & $\mathrm{II} / \mathrm{III}$ & Europe & $\begin{array}{c}\text { Epirubicin + Cisplatin + } \\
\text { 5-FU or Capecitabine } \\
\text { (ECF/ECX)/5-FU + } \\
\text { Leucovorin + Oxaliplatin + } \\
\text { Docetaxel (FLOT) }\end{array}$ & Completed & 11 May 2019 \\
\hline REGATTA & UMIN000001012 & $\begin{array}{l}\text { Gastric cancer with } \\
\text { a single non-curable } \\
\text { factor }\end{array}$ & 1 & III & Asia & $\begin{array}{c}\text { Oral S-1 + } \\
\text { Cisplatin/Gastrectomy } \\
\text { followed by oral S-1 + } \\
\text { Cisplatin }\end{array}$ & Completed & March, 2016 \\
\hline $\begin{array}{l}\text { RENAISSANCE } \\
\text { (AIO-FLOT5) }\end{array}$ & NCT02578368 & $\begin{array}{l}\text { Limited metastatic } \\
\text { gastric + GEJ } \\
\text { adenocarcinoma }\end{array}$ & 1 & III & Europe & $\begin{array}{l}\text { 5-Fluorouracil + Leucovorin } \\
\text { + Oxaliplatin + Docetaxel } \\
\text { (FLOT)/FLOT + gastrectomy }\end{array}$ & Recruiting & December, 2021 \\
\hline TOGA & NCT01041404 & $\begin{array}{l}\text { Gastric + GEJ } \\
\text { adenocarcinoma, } \\
\text { HER2-positive }\end{array}$ & 1 & III & $\begin{array}{l}\text { Europe, Asia, } \\
\text { Australia, Africa, } \\
\text { South America }\end{array}$ & $\begin{array}{c}\text { Cisplatin + 5-FU or } \\
\text { Capecitabine/Cisplatin }+ \\
\text { 5-FU or Capecitabine + } \\
\text { Trastuzumab }\end{array}$ & Completed & 28 August 2010 \\
\hline LOGIC & NCT00680901 & $\begin{array}{c}\text { Oesophageal + } \\
\text { gastric + GEJ } \\
\text { adenocarcinoma, } \\
\text { HER2-positive }\end{array}$ & 1 & III & $\begin{array}{l}\text { North and South } \\
\text { America, Europe, } \\
\text { Asia }\end{array}$ & $\begin{array}{c}\text { Capecitabine + Oxaliplatin + } \\
\text { Lapatinib/Capecitabine + } \\
\text { Oxaliplatin + Placebo }\end{array}$ & $\begin{array}{l}\text { Active, } \\
\text { not recruiting }\end{array}$ & 10 February 2016 \\
\hline JACOB & NCT01774786 & $\begin{array}{l}\text { Gastric + GEJ } \\
\text { adenocarcinoma, } \\
\text { HER2-positive }\end{array}$ & 1 & III & $\begin{array}{c}\text { North and South } \\
\text { America, Europe, } \\
\text { Asia }\end{array}$ & $\begin{array}{c}\text { Cisplatin + 5-FU or } \\
\text { Capecitabine + Trastuzumab } \\
\text { + Pertuzumab/Cisplatin }+ \\
\text { 5-FU or Capecitabine + } \\
\text { Trastuzumab + Placebo }\end{array}$ & $\begin{array}{l}\text { Active, } \\
\text { not recruiting }\end{array}$ & 11 September 2018 \\
\hline
\end{tabular}


Table 1. Cont

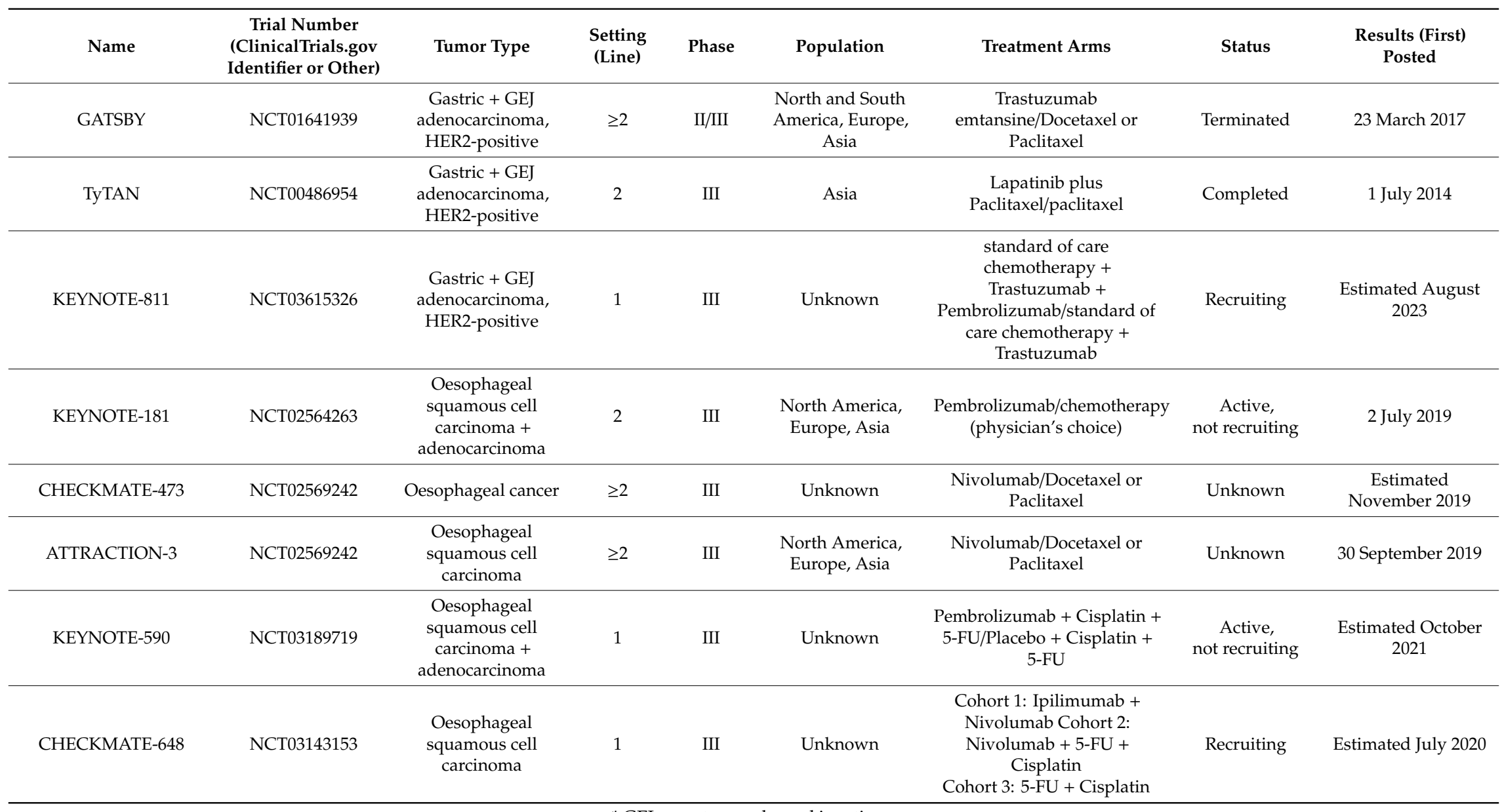


Table 2. Recent and expected approvals of second as well as third and further line therapy strategies in locally advanced and metastatic settings.

\begin{tabular}{|c|c|c|c|c|c|c|c|}
\hline \multicolumn{4}{|c|}{ Third and Further Lines } & \multicolumn{4}{|c|}{ Second Line } \\
\hline Treatment & Trial Name & Tumor Type & Approval & Treatment & Trial Name & Tumor Type & Approval \\
\hline Nivolumab & ATTRACTION-II & $\begin{array}{c}\text { Gastric or GEJ } \\
\text { adenocarcinoma }\end{array}$ & $\begin{array}{c}\text { 2018: Japan, } \\
\text { Taiwan, } \\
\text { South Korea }\end{array}$ & Ramucirumab & REGARD & $\begin{array}{c}\text { Gastric or GEJ } \\
\text { adenocarcinoma }\end{array}$ & $\begin{array}{l}\text { 2014: } \\
\text { United States, } \\
\text { Europe }\end{array}$ \\
\hline Pembrolizumab & KEYNOTE-059 & $\begin{array}{c}\text { Gastric or GEJ } \\
\text { adenocarcinoma, } \\
\text { CPS } \geq 1\end{array}$ & $\begin{array}{c}\text { 2017: } \\
\text { United States }\end{array}$ & $\begin{array}{c}\text { Ramucirumab + } \\
\text { Paclitaxel }\end{array}$ & RAINBOW & $\begin{array}{c}\text { Gastric or GEJ } \\
\text { adenocarcinoma }\end{array}$ & $\begin{array}{c}\text { 2014: } \\
\text { United States, } \\
\text { Europe }\end{array}$ \\
\hline Apatinib & ANGEL & $\begin{array}{c}\text { Gastric or GEJ } \\
\text { adenocarcinoma }\end{array}$ & 2014: China & Nab-Paclitaxel & ABSOLUTE & $\begin{array}{c}\text { Gastric or GEJ } \\
\text { adenocarcinoma }\end{array}$ & 2013: Japan \\
\hline \multirow[t]{3}{*}{$\begin{array}{l}\text { Trifluridine and } \\
\text { Tipiracil }\end{array}$} & TAGS & $\begin{array}{c}\text { Gastric or GEJ } \\
\text { adenocarcinoma }\end{array}$ & $\begin{array}{c}2019: \\
\text { United States, } \\
\text { Europe }\end{array}$ & Pembrolizumab & KEYNOTE-181 & $\begin{array}{c}\text { Oesophageal SCC } \\
\text { + adenocarcinoma, } \\
\text { CPS } \geq 10\end{array}$ & $\begin{array}{c}\text { 2019: } \\
\text { United States }\end{array}$ \\
\hline & & & & Nivolumab & ATTRACTION-III & Oesophageal SCC & Not yet approved \\
\hline & & & & Pembrolizumab & $\begin{array}{l}5 \text { KEYNOTE } \\
\text { studies }\end{array}$ & $\begin{array}{c}\text { MSI-H (tissue } \\
\text { agnostic approval) }\end{array}$ & $\begin{array}{c}\text { 2017: } \\
\text { United States }\end{array}$ \\
\hline
\end{tabular}


In the last decade there are numerous studies with promising study designs, especially considering immunotherapies and targeted therapies. Since inhibition of checkpoints changed the treatment paradigm in various of tumour types including those derived from lung, kidney or oropharynx, it was surmised that gastroesophageal cancer patients might also have a benefit from this new treatment option. However, in large part trials with checkpoint inhibitors failed to meet these high expectations. Only under certain clinical conditions immunotherapy agents have demonstrated to provide an improved prognosis when compared to standard care, and led to approval by some authorities. These drugs as well as their approval status can be seen in Table 2.

The ATTRACTION-2 and the KEYNOTE-059 trials provide robust evidence for the use of nivolumab and pembrolizumab, respectively, in a third-line setting for appropriate patients [5,6]. Thus, these drugs were already approved by some Asian and American authorities, respectively. However, both studies evaluated immunotherapy in salvage setting and there was a lack of a control group in the KEYNOTE-059 trial, whereas the ATTRACTION-2 trial only had treatment with placebo as a control arm. These results are a major breakthrough considering new treatment options, but have to be evaluated in comparison to other drugs, particularly with regard to new chemotherapeutics, which also prolong the overall survival with a reasonable amount of adverse events. The combination chemotherapy with trifluridine and tipiracil was evaluated as a third line treatment in the TAGS trial, which led to the drug approval in this setting in the United States of America as well as in Europe due to the significant improvement of overall survival compared with placebo. Since this combination chemotherapy is administered orally, the quality of life of patients might benefit in the sense that they do not have to be hospitalized for the treatment itself [38]. Nevertheless, emphasis has to be placed on the fact, that this new chemotherapy regimen was also evaluated in a placebo-controlled trial.

Another factor to consider when determining whether targeted therapy, immunotherapy or chemotherapy is more appropriate in advanced gastroesophageal cancer is the individual's tumour profile. Therefore, the proposed new classification of gastric cancer subtypes by the TCGA might play an important role in further clinical trials and consequently new treatment decisions. Although nivolumab was approved in a third line setting in Asia regardless of the molecular profile and combined positive score, there are several findings in other studies, which emphasise different responses in different tumour subgroups. In the KEYNOTE-181 trial pembrolizumab was most effective in the subgroup with combined positive score $\geq 10$ and a post hoc analysis of the KEYNOTE-061 trial showed that microsatellite instability high tumours showed the most promising response to checkpoint-inhibition $[13,54]$. These results are strengthened by the findings of the KEYNOTE-062 trial that showed the greatest benefit and clinically meaningful improvement of overall survival in patients with high expression of programmed cell death receptor ligand 1 with a combined positive score $\geq 10$. Furthermore, the Kaplan-Meier survival curves of the KEYNOTE-062 trial insinuate that (combination) immunotherapy in some patients even has a worse survival rate in the first few months of administration compared to chemotherapy, the curves then cross each other and (combination) immunotherapy shows promising results in the long term. Thus, new treatment schedules with first 3-6 months chemotherapy followed by immunotherapy maintenance might pose as reasonable treatment options to improve the overall survival and therefore most likely will be tested in further trials.

Also, it is surmised, that some targeted therapies might have a better benefit in an Asian population due to the already demonstrated exhibition of distinct gene-expression signatures related to T-cell function compared with non-Asian patients [93]. Different genetic and molecular subtypes in different populations might also be the reason why apatinib (rivoceranib) is an established and approved third line therapy in China, but failed to provide satisfactory results in a Western cohort within the ANGEL trial [20]. Thus, a better understanding and more insight in the molecular profiling of cancer subgroups, might also provide us with better treatment strategies for individual patients. 
Other trials, discussed in this review, were conducted to compare immunotherapy to standard treatment options in second or further line settings and found no significant difference in the median OS [12,13]. However, immunotherapy and targeted therapy might still be valid treatment options compared with standard chemotherapy in a second line setting due to their favourable safety and toxicity profiles. In the KEYNOTE-061 trial, for example, there was no benefit in the overall survival for patients treated with pembrolizumab compared to standard treatment with Paclitaxel, however, grade 3-5 treatment-related adverse events occurred in only $14 \%$ of the patients treated with the checkpoint-inhibitor and in 35\% of the patients treated with chemotherapy [13]. The KEYNOTE-062 trial demonstrated the favourable safety profile of pembrolizumab compared to chemotherapy. Grade 3-5 drug-related adverse event rates were $17 \%$ with pembrolizumab, $73 \%$ with immunochemotherapy and $69 \%$ chemotherapy alone [18]. Hence, the toxicity profile of therapies has to be considered and discussed with the patient when deciding which therapy is the best, particularly for the patients with biomarker positivity. It was, however, surprising to see that the documented better toxicity profile of pembrolizumab was not translated into an improved quality of life in patients with pembrolizumab monotherapy when compared to chemotherapy [17]. Further subgroup analysis and long-term results of this data are however lacking. It is therefore important to integrate the quality of life assessments into clinical trials, particularly those questionnaires that focus on the specific symptoms and problems of gastroesophageal tumour patients.

Not only new adverse events, but also residual toxicity from prior therapies, for example neutropenia and polyneuropathy, have to be taken into consideration before a new treatment strategy can be fixed. Comorbidities such as renal and hepatic impairment might also limit therapeutic options. Thus, study designs to show non-inferiority of new agents are therefore a solid way to evaluate better toxicity profiles and to expand treatment strategies and improve the quality of life for patients with metastatic cancer of the upper gastrointestinal tract. The ABSOLUTE study was powered for non-inferiority and could show the advantages of the nab-paclitaxel formulation considering adverse events as well as pharmacokinetics, thus leading to its approval in Japan [42]. Currently, several treatment regimens including nivolumab, pembrolizumab, trifluradine/tipiracil and apatinib are proven to be effective in salvage settings. In order to define an appropriate treatment algorithm for the individual patients, such non-inferiority trials will most probably gain more importance in the future.

Another important issue when discussing novel treatment options is financial toxicity. The costs of new treatment options might exceed the patient's or health-care system's limits. Consequently, new drugs which are non-inferior to already established (and therefore most of the time significantly cheaper) treatment options might not find their way into everyday practice. Thus, it is important for clinical trials to evaluate the real-life benefit of novel drug regimens, so that the financial toxicity can be related to the benefits for the patient. The ESMO-Magnitude of Clinical Benefit Scale (ESMO-MCSBS) or ASCO Value Framework Net Health Benefit Score are such tools to stratify the magnitude of clinical benefit that can be anticipated from anticancer therapies [94,95]. Clinical benefit scales should be evaluated in further clinical trials and also involved in individual decision making to optimize patient care and minimize financial toxicity without benefit.

For now, clinical experience from recent studies in gastroesophageal cancer patients but also in other entities might help decide on the best treatment strategies for patients with gastroesophageal cancer. New treatment options, that were approved in the last few years, as well as new study designs might lead to a longer overall survival as well as a better quality of life of patients with upper gastrointestinal cancer in the future. Although, there have been great advances in the diagnosis, understanding and treatment in the last decade, new therapeutic options are still in their infancy. Further studies are necessary to optimize patient care. 
Author Contributions: The manuscript of this review article has been read and approved by all authors. All authors contributed to the preparation of the manuscript significantly and are in agreement with the content of the manuscript. All authors have read and agreed to the published version of the manuscript.

Funding: This research received no external funding.

Acknowledgments: The authors gratefully acknowledge Medical University of Vienna's core funding to the Department of Internal Medicine I.

Conflicts of Interest: H.C.P. has received travel support from Eli Lilly, MSD, Novartis, Pfizer and Roche. A.I.-M. participated in advisory boards from MSD and Servier, received lecture honoraria from Eli Lilly and Servier, received travel support from Roche and MSD, is the local PI for clinical trials sponsored by BMS and Astellas. M.P. has received honoraria for lectures, consultation or advisory board participation from the following for-profit companies: Bayer, Bristol-Myers Squibb, Novartis, Gerson Lehrman Group (GLG), CMC Contrast, GlaxoSmithKline, Mundipharma, Roche, BMJ Journals, MedMedia, Astra Zeneca, AbbVie, Lilly, Medahead, Daiichi Sankyo, Sanofi, Merck Sharp \& Dome, Tocagen. The following for-profit companies have supported clinical trials and contracted research conducted by M.P. with payments made to his institution: Böhringer-Ingelheim, Bristol-Myers Squibb, Roche, Daiichi Sankyo, Merck Sharp \& Dome, Novocure, GlaxoSmithKline, AbbVie. G.P. has received honoraria for lectures, consultation or advisory board participation from the following for-profit companies: Bayer, Bristol-Myers Squibb, Roche, MedMedia, Lilly, Medahead, Sanofi, Merck Sharp \& Dome, Merck, Amgen, Celgene, Servier, Pierre-Fabre.

$\begin{array}{ll}\text { Abbreviations } \\ \text { CI } & \text { confidence interval } \\ \text { CPS } & \text { combined positive score } \\ \text { EBV } & \text { Epstein-Barr Virus } \\ \text { EMA } & \text { European Medicines Agency } \\ \text { FDA } & \text { U.S. Food and Drug Administration } \\ \text { HR } & \text { hazard ratio } \\ \text { MSI } & \text { microsatellite instability } \\ \text { MSI-H } & \text { microsatellite instability high } \\ \text { OS } & \text { overall survival } \\ \text { PD-1 } & \text { programmed cell death receptor 1 } \\ \text { PD-L1 } & \text { programmed cell death receptor ligand 1 } \\ \text { QoL } & \text { quality of life }\end{array}$

\section{References}

1. Bray, F.; Ferlay, J.; Soerjomataram, I.; Siegel, R.L.; Torre, L.A.; Jemal, A. Global cancer statistics 2018: GLOBOCAN estimates of incidence and mortality worldwide for 36 cancers in 185 countries. CA A Cancer J. Clin. 2018, 68, 394-424. [CrossRef] [PubMed]

2. Rivera, F.; Carrato, A.; Gravalos, C.; Pericay, C.; Sastre, J.; Aranda, E. Recommendations on current approach to gastric cancer. Clin. Transl. Oncol. Off. Publ. Fed. Span. Oncol. Soc. Natl. Cancer Inst. Mex. 2009, 11, 518-525. [CrossRef] [PubMed]

3. National Cancer Institute Bethesda MD. SEER Cancer Stat Facts: Esophageal Cancer. Available online: https://seer.cancer.gov/statfacts/html/esoph.html (accessed on 25 November 2019).

4. National Cancer Institute Bethesda MD. SEER Cancer Stat Facts: Stomach Cancer. Available online: https://seer.cancer.gov/statfacts/html/stomach.html (accessed on 25 November 2019).

5. Kang, Y.-K.; Boku, N.; Satoh, T.; Ryu, M.-H.; Chao, Y.; Kato, K.; Chung, H.C.; Chen, J.-S.; Muro, K.; Kang, W.K.; et al. Nivolumab in patients with advanced gastric or gastro-oesophageal junction cancer refractory to, or intolerant of, at least two previous chemotherapy regimens (ONO-4538-12, ATTRACTION-2): A randomised, double-blind, placebo-controlled, phase 3 trial. Lancet 2017, 390, 2461-2471. [CrossRef]

6. Fuchs, C.S.; Doi, T.; Jang, R.W.; Muro, K.; Satoh, T.; Machado, M.; Sun, W.; Jalal, S.I.; Shah, M.A.; Metges, J.P.; et al. Safety and Efficacy of Pembrolizumab Monotherapy in Patients With Previously Treated Advanced Gastric and Gastroesophageal Junction Cancer: Phase 2 Clinical KEYNOTE-059 Trial. JAMA Oncol. 2018, 4, e180013. [CrossRef] 
7. Wainberg, Z.A.; Yoon, H.H.; Catenacci, D.V.T.; Jalal, S.I.; Muro, K.; Garrido, M.; Golan, T.; Doi, T.; Geva, R.; $\mathrm{Ku}, \mathrm{G}$.Y.; et al. Efficacy and safety of pembrolizumab (pembro) alone or in combination with chemotherapy (chemo) in patients (pts) with advanced gastric or gastroesophageal (G/GEJ) cancer: Long-term follow up from KEYNOTE-059. J. Clin. Oncol. 2019, 37, 4009. [CrossRef]

8. Ono Pharmaceutical Co Ltd. Opdivo ${ }^{\circledR}$ (Nivolumab) intravenous infusion approved in Taiwan for supplemental indication of advanced or recurrent gastric cancer or gastro-esophageal junction cancer. Available online: http://www.publicnow.com/view/22234ED594EACD6AF6D272B5A36B02885602E774 (accessed on 11 November 2019).

9. Ono Pharmaceutical Co Ltd. Opdivo ${ }^{\circledR}$ (Nivolumab) intravenous infusion approved for supplemental indication of advanced or recurrent gastric or gastroesophageal junction adenocarcinoma and for expanded use in recurrent or advanced classical Hodgkin lymphoma in South Korea. Available online: https: //www.ono.co.jp/eng/news/pdf/sm_cn180326.pdf (accessed on 11 November 2019).

10. US Food and Drug Administration. FDA grants accelerated approval to pembrolizumab for advanced gastric cancer. Available online: https://www.fda.gov/Drugs/InformationOnDrugs/ApprovedDrugs/ucm577093.htm (accessed on 11 November 2019).

11. The ASCO post. Nivolumab Approved in Japan for Unresectable Advanced or Recurrent Gastric Cancer That Has Progressed After Chemotherapy. Available online: https://www.ascopost.com/News/58104 (accessed on 26 December 2019).

12. Bang, Y.J.; Ruiz, E.Y.; Van Cutsem, E.; Lee, K.W.; Wyrwicz, L.; Schenker, M.; Alsina, M.; Ryu, M.H.; Chung, H.C.; Evesque, L.; et al. Phase III, randomised trial of avelumab versus physician's choice of chemotherapy as third-line treatment of patients with advanced gastric or gastro-oesophageal junction cancer: Primary analysis of JAVELIN Gastric 300. Ann. Oncol. 2018, 29, 2052-2060. [CrossRef]

13. Shitara, K.; Özgüroğlu, M.; Bang, Y.-J.; Di Bartolomeo, M.; Mandalà, M.; Ryu, M.-H.; Fornaro, L.; Olesiński, T.; Caglevic, C.; Chung, H.C.; et al. Pembrolizumab versus paclitaxel for previously treated, advanced gastric or gastro-oesophageal junction cancer (KEYNOTE-061): A randomised, open-label, controlled, phase 3 trial. Lancet 2018, 392, 123-133. [CrossRef]

14. Efficacy Study of Nivolumab Plus Ipilimumab or Nivolumab Plus Chemotherapy Against Chemotherapy in Stomach Cancer or Stomach/Esophagus Junction Cancer (CheckMate649). Available online: https: //clinicaltrials.gov/ct2/show/NCT02872116 (accessed on 7 November 2019).

15. Tabernero, J.; Van Cutsem, E.; Bang, Y.-J.; Fuchs, C.S.; Wyrwicz, L.; Wook Lee, K.; Kudaba, I.; Garrido, M.; Cheol Chung, H.; Castro Salguero, H.R.; et al. Pembrolizumab with or without chemotherapy versus chemotherapy for advanced gastric or gastroesophageal junction (G/GEJ) adenocarcinoma: The phase III KEYNOTE-062 study. Available online: https://meetinglibrary.asco.org/record/173187/abstract (accessed on 7 November 2019).

16. Bang, Y.J.; Kang, Y.K.; Catenacci, D.V.; Muro, K.; Fuchs, C.S.; Geva, R.; Hara, H.; Golan, T.; Garrido, M.; Jalal, S.I.; et al. Pembrolizumab alone or in combination with chemotherapy as first-line therapy for patients with advanced gastric or gastroesophageal junction adenocarcinoma: Results from the phase II nonrandomized KEYNOTE-059 study. Gastric Cancer 2019, 22, 828-837. [CrossRef]

17. Van Cutsem, E.; Valderrama, A.; Bang, Y.-J.; Fuchs, C.; Shitara, K.; Janjigian, Y.Y.; Qin, S.; Larson, T.; Shankaran, V.; Stein, S.; et al. LBA45Health-related quality of life (HRQoL) impact of pembrolizumab (P) versus chemotherapy $(\mathrm{C})$ as first-line $(1 \mathrm{~L})$ treatment in PD-L1-positive advanced gastric or gastroesophageal junction (G/GEJ) adenocarcinoma. Ann. Oncol. 2019, 30. [CrossRef]

18. Shitara, K.; Van Cutsem, E.; Bang, Y.; Fuchs, C.S.; Wyrwicz, L.; Lee, K.W.; Kudaba, I.; Garrido, M.; Cheol Chung, H.; Castro, H.R.; et al. Pembrolizumab With or Without Chemotherapy vs Chemotherapy in Patients With Advanced G/GEJ Cancer (GC) Including Outcomes According to Microsatellite Instability-High Status in KEYNOTE-062. Available online: https:/oncologypro.esmo.org/Meeting-Resources/ESMO-2019-Congress/PembrolizumabWith-or-Without-Chemotherapy-vs-Chemotherapy-in-Patients-With-Advanced-G-GEJ-Cancer-GCIncluding-Outcomes-According-to-Microsatellite-Instability-High-MSI-H-Status-in-KEYNOTE-062 (accessed on 26 November 2019).

19. Aoyama, T.; Yoshikawa, T. Apatinib-New third-line option for refractory gastric or GEJ cancer. Nat. Rev. Clin. Oncol. 2016, 13, 268-270. [CrossRef] 
20. Kang, Y.; Kang, W.K.; Di Bartolomeo, M.; Chau, I.; Yoon, H.H.; Cascinu, S.; Ryu, M.; Kim, J.G.; Lee, K.; Oh, S.C.; et al. Randomized phase 3 ANGEL study of rivoceranib (apatinib) + best supportive care (BSC) vs placebo + BSC in patients with advanced/metastatic gastric cancer. Available online: https://oncologypro.esmo.org/Meeting-Resources/ESMO-2019-Congress/Randomized-phase-3-ANGELstudy-of-rivoceranib-apatinib-best-supportive-care-BSC-vs-placebo-BSC-in-patients-with-advancedmetastatic-gastric-cancer-who-failed-_2-prior-chemotherapy-regimens (accessed on 7 November 2019).

21. Sjoquist, K.M.; Pavlakis, N.; Martin, A.J.; Tsobanis, E.; Yip, S.; Bang, Y.-J.; Alcindor, T.; O'Callaghan, C.J.; Shitara, K.; Bekaii-Saab, T.S.; et al. Integrate II: A randomised phase 3 double-blind placebo-controlled study of regorafenib in refractory advanced gastro-oesophageal cancer (AGOC)—An international study organized by the Australasian Gastrointestinal Trials Group (AGITG). J. Clin. Oncol. 2017, 35, TPS4136. [CrossRef]

22. Fukuoka, S.; Hara, H.; Takahashi, N.; Kojima, T.; Kawazoe, A.; Asayama, M.; Yoshii, T.; Kotani, D.; Tamura, H.; Mikamoto, Y.; et al. Regorafenib plus nivolumab in patients with advanced gastric (GC) or colorectal cancer (CRC): An open-label, dose-finding, and dose-expansion phase $1 \mathrm{~b}$ trial (REGONIVO, EPOC1603). J. Clin. Oncol. 2019, 37, 2522. [CrossRef]

23. Wilke, H.; Muro, K.; Van Cutsem, E.; Oh, S.-C.; Bodoky, G.; Shimada, Y.; Hironaka, S.; Sugimoto, N.; Lipatov, O.; Kim, T.-Y.; et al. Ramucirumab plus paclitaxel versus placebo plus paclitaxel in patients with previously treated advanced gastric or gastro-oesophageal junction adenocarcinoma (RAINBOW): A double-blind, randomised phase 3 trial. Lancet Oncol. 2014, 15, 1224-1235. [CrossRef]

24. Fuchs, C.S.; Tomasek, J.; Yong, C.J.; Dumitru, F.; Passalacqua, R.; Goswami, C.; Safran, H.; Dos Santos, L.V.; Aprile, G.; Ferry, D.R.; et al. Ramucirumab monotherapy for previously treated advanced gastric or gastro-oesophageal junction adenocarcinoma (REGARD): An international, randomised, multicentre, placebo-controlled, phase 3 trial. Lancet 2014, 383, 31-39. [CrossRef]

25. Casak, S.J.; Fashoyin-Aje, I.; Lemery, S.J.; Zhang, L.; Jin, R.; Li, H.; Zhao, L.; Zhao, H.; Zhang, H.; Chen, H.; et al. FDA Approval Summary: Ramucirumab for Gastric Cancer. Clin. Cancer Res. 2015, 21, 3372-3376. [CrossRef]

26. EPAR summary for the public - Cyramza (ramucirumab). Available online: https://www.ema.europa.eu/en/ documents/overview/cyramza-epar-summary-public_en.pdf (accessed on 11 November 2019).

27. Di Bartolomeo, M.; Niger, M.; Tirino, G.; Petrillo, A.; Berenato, R.; Laterza, M.M.; Pietrantonio, F.; Morano, F.; Antista, M.; Lonardi, S.; et al. Ramucirumab as Second-Line Therapy in Metastatic Gastric Cancer: Real-World Data from the RAMoss Study. Target. Oncol. 2018, 13, 227-234. [CrossRef]

28. Shah, M.A.; Shitara, K.; Lordick, F.; Bang, Y.-J.; Tebbutt, N.C.; Metges, J.-P.; Muro, K.; Shen, L.; Tjulandin, S.; Hays, J.L.; et al. The BRIGHTER trial: A phase 3 randomized double-blind study of napabucasin (NAPA) plus paclitaxel (PTX) versus placebo (PBO) plus PTX in patients (pts) with pretreated advanced gastric and gastroesophageal junction (GEJ) adenocarcinoma. J. Clin. Oncol. 2018, 36, 4010. [CrossRef]

29. Lordick, F.; Kang, Y.K.; Chung, H.C.; Salman, P.; Oh, S.C.; Bodoky, G.; Kurteva, G.; Volovat, C.; Moiseyenko, V.M.; Gorbunova, V.; et al. Capecitabine and cisplatin with or without cetuximab for patients with previously untreated advanced gastric cancer (EXPAND): A randomised, open-label phase 3 trial. Lancet Oncol. 2013, 14, 490-499. [CrossRef]

30. Waddell, T.; Chau, I.; Cunningham, D.; Gonzalez, D.; Okines, A.F.C.; Okines, C.; Wotherspoon, A.; Saffery, C.; Middleton, G.; Wadsley, J.; et al. Epirubicin, oxaliplatin, and capecitabine with or without panitumumab for patients with previously untreated advanced oesophagogastric cancer (REAL3): A randomised, open-label phase 3 trial. Lancet. Oncol. 2013, 14, 481-489. [CrossRef]

31. Catenacci, D.V.T.; Tebbutt, N.C.; Davidenko, I.; Murad, A.M.; Al-Batran, S.-E.; Ilson, D.H.; Tjulandin, S.; Gotovkin, E.; Karaszewska, B.; Bondarenko, I.; et al. Rilotumumab plus epirubicin, cisplatin, and capecitabine as first-line therapy in advanced MET-positive gastric or gastro-oesophageal junction cancer (RILOMET-1): A randomised, double-blind, placebo-controlled, phase 3 trial. Lancet Oncol. 2017, 18, 1467-1482. [CrossRef]

32. Shah, M.A.; Bang, Y.J.; Lordick, F.; Alsina, M.; Chen, M.; Hack, S.P.; Bruey, J.M.; Smith, D.; McCaffery, I.; Shames, D.S.; et al. Effect of Fluorouracil, Leucovorin, and Oxaliplatin With or Without Onartuzumab in HER2-Negative, MET-Positive Gastroesophageal Adenocarcinoma: The METGastric Randomized Clinical Trial. JAMA Oncol. 2017, 3, 620-627. [CrossRef] [PubMed] 
33. Kang, Y.; Ohtsu, A.; Van Cutsem, E.; Rha, S.Y.; Sawaki, A.; Park, S.; Lim, H.; Wu, J.; Langer, B.; Shah, M.A. AVAGAST: A randomized, double-blind, placebo-controlled, phase III study of first-line capecitabine and cisplatin plus bevacizumab or placebo in patients with advanced gastric cancer (AGC). J. Clin. Oncol. 2010, 28, LBA4007. [CrossRef]

34. Shen, L.; Li, J.; Xu, J.; Pan, H.; Dai, G.; Qin, S.; Wang, L.; Wang, J.; Yang, Z.; Shu, Y.; et al. Bevacizumab plus capecitabine and cisplatin in Chinese patients with inoperable locally advanced or metastatic gastric or gastroesophageal junction cancer: Randomized, double-blind, phase III study (AVATAR study). Gastric Cancer 2015, 18, 168-176. [CrossRef] [PubMed]

35. Fuchs, C.S.; Shitara, K.; Di Bartolomeo, M.; Lonardi, S.; Al-Batran, S.-E.; Van Cutsem, E.; Ilson, D.H.; Alsina, M.; Chau, I.; Lacy, J.; et al. Ramucirumab with cisplatin and fluoropyrimidine as first-line therapy in patients with metastatic gastric or junctional adenocarcinoma (RAINFALL): A double-blind, randomised, placebo-controlled, phase 3 trial. Lancet Oncol. 2019, 20, 420-435. [CrossRef]

36. Shah, M.A. Andecaliximab in Untreated Gastric or Gastroesophageal Junction Cancer. Available online: https://ascopost.com/issues/february-10-2019/andecaliximab-in-untreated-gastric-or-gastroesophagealjunction-cancer/ (accessed on 25 November 2019).

37. Schuler, M.; Al-Batran, S.E.; Zvirbule, Z.; Manikhas, G.; Lordick, F.; Rusyn, A.; Vinnyk, Y.; Vynnychenko, I.; Fadeeva, N.; Nechaeva, M.; et al. Final results of the FAST study, an international, multicenter, randomized, phase II trial of epirubicin, oxaliplatin, and capecitabine (EOX) with or without the anti-CLDN18.2 antibody IMAB362 as first-line therapy in patients with advanced CLDN18.2+ gastric and gastroesophageal junction (GEJ) adenocarcinoma. Ann. Oncol. 2016, 27. [CrossRef]

38. Shitara, K.; Doi, T.; Dvorkin, M.; Mansoor, W.; Arkenau, H.-T.; Prokharau, A.; Alsina, M.; Ghidini, M.; Faustino, C.; Gorbunova, V.; et al. Trifluridine/tipiracil versus placebo in patients with heavily pretreated metastatic gastric cancer (TAGS): A randomised, double-blind, placebo-controlled, phase 3 trial. Lancet Oncol. 2018, 19, 1437-1448. [CrossRef]

39. Ilson, D.H.; Tabernero, J.; Prokharau, A.; Arkenau, H.-T.; Ghidini, M.; Fujitani, K.; Van Cutsem, E.; Thuss-Patience, P.; Beretta, G.D.; Mansoor, W.; et al. Efficacy and Safety of Trifluridine/Tipiracil Treatment in Patients With Metastatic Gastric Cancer Who Had Undergone Gastrectomy: Subgroup Analyses of a Randomized Clinical Trial. JAMA Oncol. 2019. [CrossRef]

40. Alsina, M.; Tabernero, J.; Shitara, K.; Doi, T.; Dvorkin, M.; Mansoor, W.; Arkenau, H.-T.; Prokharau, A.; Ghidini, M.; Faustino, C.; et al. Analysis of symptoms and functional HRQoL scales in TAGS, a phase III trial of trifluridine/tipiracil (FTD/TPI) in metastatic gastric cancer (mGC). J. Clin. Oncol. 2019, 37, 4043. [CrossRef]

41. FDA approves Lonsurf for recurrent, metastatic gastric and gastroesophageal junction adenocarcinoma. Available online: https://www.fda.gov/drugs/drug-approvals-and-databases/fda-approves-lonsurf-recurrentmetastatic-gastric-and-gastroesophageal-junction-adenocarcinoma (accessed on 11 November 2019).

42. Shitara, K.; Takashima, A.; Fujitani, K.; Koeda, K.; Hara, H.; Nakayama, N.; Hironaka, S.; Nishikawa, K.; Makari, Y.; Amagai, K.; et al. Nab-paclitaxel versus solvent-based paclitaxel in patients with previously treated advanced gastric cancer (ABSOLUTE): An open-label, randomised, non-inferiority, phase 3 trial. Lancet Gastroenterol. Hepatol. 2017, 2, 277-287. [CrossRef]

43. Antitumor Agent Abraxane ${ }^{\circledR}$ I.V. Infusion $100 \mathrm{mg}$ Approved for Additional Dosage and Administration for Gastric Cancer. Available online: https://www.taiho.co.jp/en/release/2017/20170825.html (accessed on 11 November 2019).

44. Ford, H.E.; Marshall, A.; Bridgewater, J.A.; Janowitz, T.; Coxon, F.Y.; Wadsley, J.; Mansoor, W.; Fyfe, D.; Madhusudan, S.; Middleton, G.W.; et al. Docetaxel versus active symptom control for refractory oesophagogastric adenocarcinoma (COUGAR-02): An open-label, phase 3 randomised controlled trial. Lancet Oncol. 2014, 15, 78-86. [CrossRef]

45. Hironaka, S.; Ueda, S.; Yasui, H.; Nishina, T.; Tsuda, M.; Tsumura, T.; Sugimoto, N.; Shimodaira, H.; Tokunaga, S.; Moriwaki, T.; et al. Randomized, open-label, phase III study comparing irinotecan with paclitaxel in patients with advanced gastric cancer without severe peritoneal metastasis after failure of prior combination chemotherapy using fluoropyrimidine plus platinum: WJOG 4007 trial. J. Clin. Oncol. 2013, 31, 4438-4444. [CrossRef] [PubMed] 
46. Al-Batran, S.-E.; Homann, N.; Pauligk, C.; Goetze, T.O.; Meiler, J.; Kasper, S.; Kopp, H.-G.; Mayer, F.; Haag, G.M.; Luley, K.; et al. Perioperative chemotherapy with fluorouracil plus leucovorin, oxaliplatin, and docetaxel versus fluorouracil or capecitabine plus cisplatin and epirubicin for locally advanced, resectable gastric or gastro-oesophageal junction adenocarcinoma (FLOT4): A randomised, phase 2/3 trial. Lancet 2019, 393, 1948-1957. [CrossRef] [PubMed]

47. Fokter-Dovnik, N.; Smyth, E.C. More is not always better: Triplet chemotherapy and advanced gastric cancer. Lancet Gastroenterol. Hepatol. 2019, 4, 490-491. [CrossRef]

48. Diaz-Guardamino, I.E.; Carmona-Bayonas, A.; Fonseca, P.J.; Martin, A.J.M.; Lorenzo, M.L.S.; Custodio, A.; Garrido, M.; Cano, J.M.; Barreto, J.E.L.; Lacalle, A.; et al. First-line triplet or doublet chemotherapy for advanced gastric cancer: Analysis of 970 patients from a community practice registry. Ann. Oncol. 2016, 27. [CrossRef]

49. Laterza, M.M.; Pompella, L.; Petrillo, A.; Tirino, G.; Pappalardo, A.; Orditura, M.; Troiani, T.; Ciardiello, F.; Di Martino, N.; De Vita, F. Efficacy of a triplet and doublet-based chemotherapy as first-line therapy in patients with HER2-negative metastatic gastric cancer: A retrospective analysis from the clinical practice. Med. Oncol. 2017, 34, 186. [CrossRef]

50. Guo, X.; Zhao, F.; Ma, X.; Shen, G.; Ren, D.; Zheng, F.; Du, F.; Wang, Z.; Ahmad, R.; Yuan, X.; et al. A comparison between triplet and doublet chemotherapy in improving the survival of patients with advanced gastric cancer: A systematic review and meta-analysis. BMC Cancer 2019, 19, 1125. [CrossRef]

51. Dijksterhuis, W.P.M.; Verhoeven, R.H.A.; Slingerland, M.; Haj Mohammad, N.; de Vos-Geelen, J.; Beerepoot, L.V.; van Voorthuizen, T.; Creemers, G.-J.; van Oijen, M.G.H.; van Laarhoven, H.W.M. Heterogeneity of first-line palliative systemic treatment in synchronous metastatic esophagogastric cancer patients: A real-world evidence study. Int. J. Cancer 2019. [CrossRef]

52. Fujitani, K.; Yang, H.-K.; Mizusawa, J.; Kim, Y.-W.; Terashima, M.; Han, S.-U.; Iwasaki, Y.; Hyung, W.J.; Takagane, A.; Park, D.J.; et al. Gastrectomy plus chemotherapy versus chemotherapy alone for advanced gastric cancer with a single non-curable factor (REGATTA): A phase 3, randomised controlled trial. Lancet Oncol. 2016, 17, 309-318. [CrossRef]

53. Al-Batran, S.-E.; Goetze, T.O.; Mueller, D.W.; Vogel, A.; Winkler, M.; Lorenzen, S.; Novotny, A.; Pauligk, C.; Homann, N.; Jungbluth, T.; et al. The RENAISSANCE (AIO-FLOT5) trial: Effect of chemotherapy alone vs. chemotherapy followed by surgical resection on survival and quality of life in patients with limited-metastatic adenocarcinoma of the stomach or esophagogastric junction-A phase III trial of the German AIO/CAO-V/CAOGI. BMC Cancer 2017, 17, 893. [CrossRef]

54. Kojima, T. KEYNOTE-181: Pembrolizumab vs Chemotherapy in Second-Line Treatment of Advanced Esophageal Cancer. Available online: https:/www.ascopost.com/issues/february-10-2019/keynote-181pembrolizumab-vs-chemotherapy-in-advanced-esophageal-cancer/ (accessed on 7 November 2019).

55. Kato, K.; Cho, B.C.; Takahashi, M.; Okada, M.; Lin, C.-Y.; Chin, K.; Kadowaki, S.; Ahn, M.-J.; Hamamoto, Y.; Doki, Y.; et al. Nivolumab versus chemotherapy in patients with advanced oesophageal squamous cell carcinoma refractory or intolerant to previous chemotherapy (ATTRACTION-3): A multicentre, randomised, open-label, phase 3 trial. Lancet Oncol. 2019, 20, 1506-1517. [CrossRef]

56. Cho, B.C.; Kato, K.; Takahashi, M.; Okada, C.; Lin, C.; Chin, K.; Kadowaki, S.; Ahn, M.; Hamamoto, Y.; Doki, Y.; et al. Nivolumab Versus Chemotherapy in Advanced Esophageal Squamous Cell Carcinoma (ESCC): The Phase 3 ATTRACTION-3 Study. Available online: https://oncologypro.esmo.org/Meeting-Resources/ESMO2019-Congress/Nivolumab-Versus-Chemotherapy-in-Advanced-Esophageal-Squamous-Cell-CarcinomaESCC-The-Phase-3-ATTRACTION-3-Study (accessed on 6 December 2019).

57. Kato, K.; Shah, M.A.; Enzinger, P.; Bennouna, J.; Shen, L.; Adenis, A.; Sun, J.M.; Cho, B.C.; Ozguroglu, M.; Kojima, T.; et al. KEYNOTE-590: Phase III study of first-line chemotherapy with or without pembrolizumab for advanced esophageal cancer. Future Oncol. 2019, 15, 1057-1066. [CrossRef] [PubMed]

58. Ajani, J.A.; Kato, K.; Doki, Y.; Chau, I.; Xynos, I.; Balogh, A.; Kitagawa, Y. CheckMate 648: A randomized phase 3 study of nivolumab plus ipilimumab or nivolumab combined with fluorouracil plus cisplatin versus fluorouracil plus cisplatin in patients with unresectable advanced, recurrent, or metastatic previously untreated esophageal squamous cell carcinoma. J. Clin. Oncol. 2018, 36, TPS193. [CrossRef] 
59. Bang, Y.J.; Van Cutsem, E.; Feyereislova, A.; Chung, H.C.; Shen, L.; Sawaki, A.; Lordick, F.; Ohtsu, A.; Omuro, Y.; Satoh, T.; et al. Trastuzumab in combination with chemotherapy versus chemotherapy alone for treatment of HER2-positive advanced gastric or gastro-oesophageal junction cancer (ToGA): A phase 3, open-label, randomised controlled trial. Lancet 2010, 376, 687-697. [CrossRef]

60. Hecht, J.R.; Bang, Y.J.; Qin, S.K.; Chung, H.C.; Xu, J.M.; Park, J.O.; Jeziorski, K.; Shparyk, Y.; Hoff, P.M.; Sobrero, A.; et al. Lapatinib in Combination With Capecitabine Plus Oxaliplatin in Human Epidermal Growth Factor Receptor 2-Positive Advanced or Metastatic Gastric, Esophageal, or Gastroesophageal Adenocarcinoma: TRIO-013/LOGiC-A Randomized Phase III Trial. J. Clin. Oncol. 2016, 34, 443-451. [CrossRef]

61. Tabernero, J.; Hoff, P.M.; Shen, L.; Ohtsu, A.; Shah, M.A.; Cheng, K.; Song, C.; Wu, H.; Eng-Wong, J.; Kim, K.; et al. Pertuzumab plus trastuzumab and chemotherapy for HER2-positive metastatic gastric or gastro-oesophageal junction cancer (JACOB): Final analysis of a double-blind, randomised, placebo-controlled phase 3 study. Lancet Oncol. 2018, 19, 1372-1384. [CrossRef]

62. Thuss-Patience, P.C.; Shah, M.A.; Ohtsu, A.; Van Cutsem, E.; Ajani, J.A.; Castro, H.; Mansoor, W.; Chung, H.C.; Bodoky, G.; Shitara, K.; et al. Trastuzumab emtansine versus taxane use for previously treated HER2-positive locally advanced or metastatic gastric or gastro-oesophageal junction adenocarcinoma (GATSBY): An international randomised, open-label, adaptive, phase 2/3 study. Lancet Oncol. 2017, 18, 640-653. [CrossRef]

63. Bang, Y.-J. A randomized, open-label, phase III study of lapatinib in combination with weekly paclitaxel versus weekly paclitaxel alone in the second-line treatment of HER2 amplified advanced gastric cancer (AGC) in Asian population: Tytan study. J. Clin. Oncol. 2013, 31, 11. [CrossRef]

64. Makiyama, A.; Sagara, K.; Kawada, J.; Kashiwada, T.; Hosokawa, A.; Horie, Y.; Satake, H.; Yamamoto, Y.; Tanioka, H.; Shinozaki, K.; et al. A randomized phase II study of weekly paclitaxel \pm trastuzumab in patients with HER2-positive advanced gastric or gastro-esophageal junction cancer refractory to trastuzumab combined with fluoropyrimidine and platinum: WJOG7112G (T-ACT). J. Clin. Oncol. 2018, 36, 4011. [CrossRef]

65. Saeki, H.; Oki, E.; Kashiwada, T.; Arigami, T.; Makiyama, A.; Iwatsuki, M.; Narita, Y.; Satake, H.; Matsuda, Y.; Sonoda, H.; et al. Re-evaluation of HER2 status in patients with HER2-positive advanced or recurrent gastric cancer refractory to trastuzumab (KSCC1604). Eur. J. Cancer 2018, 105, 41-49. [CrossRef]

66. Chen, Y.; Dai, G. Trastuzumab beyond progression in patients with HER2-positive advanced gastric adenocarcinoma: A retrospective real world study. J. Clin. Oncol. 2019, 37, 113. [CrossRef]

67. Palle, J.; Tougeron, D.; Pozet, A.; Soularue, E.; Artru, P.; Leroy, F.; Dubreuil, O.; Sarabi, M.; Williet, N.; Manfredi, S.; et al. Trastuzumab beyond progression in patients with HER2-positive advanced gastric adenocarcinoma: A multicenter AGEO study. Oncotarget 2017, 8, 101383-101393. [CrossRef] [PubMed]

68. Janjigian, Y.Y.; Chou, J.F.; Simmons, M.; Momtaz, P.; Sanchez-Vega, F.; Shcherba, M.; Yuyat Ku, G.; Won, E.; Chong, C.R.; Gerdes, H.; et al. First-line pembrolizumab (P), trastuzumab (T), capecitabine (C) and oxaliplatin $(\mathrm{O})$ in HER2-positive metastatic esophagogastric adenocarcinoma (mEGA). Available online: https://meetinglibrary.asco.org/record/169420/abstract (accessed on 7 November 2019).

69. Janjigian, Y.Y.; Maron, S.; Chou, J.F.; Gabler, A.R.; Simmons, M.Z.; Momtaz, P.; Shcherba, M.; Ku, G.Y.; Won, E.; Sanchez-Vega, F.; et al. First-line pembrolizumab (P), trastuzumab (T), capecitabine (C) and oxaliplatin (O) in HER2-positive metastatic esophagogastric adenocarcinoma. Available online: https:/oncologypro.esmo.org/ Meeting-Resources/ESMO-2019-Congress/First-line-pembrolizumab-P-trastuzumab-T-capecitabine-C-andoxaliplatin-O-in-HER2-positive-metastatic-esophagogastric-adenocarcinoma (accessed on 8 December 2019).

70. Chung, H.; Bang, Y.; Fuchs, C.; Qin, S.; Satoh, T.; Shitara, K.; Tabernero, J.; Van Cutsem, E.; Cao, Z.; Chen, X.; et al. P-094KEYNOTE-811 pembrolizumab plus trastuzumab and chemotherapy for HER2+ metastatic gastric or gastroesophageal junction cancer: A double-blind, randomized, placebo-controlled phase 3 study. Ann. Oncol. 2019, 30, mdz155.093. [CrossRef]

71. Pietrantonio, F.; Fucà, G.; Morano, F.; Gloghini, A.; Corso, S.; Aprile, G.; Perrone, F.; De Vita, F.; Tamborini, E.; Tomasello, G.; et al. Biomarkers of primary resistance to trastuzumab in HER2-positive metastatic gastric cancer patients: The AMNESIA case-control study. Clin. Cancer Res. 2018, 24, 1082-1089. [CrossRef] [PubMed]

72. The Cancer Genome Atlas Research Network. Comprehensive molecular characterization of gastric adenocarcinoma. Nature 2014, 513, 202-209. [CrossRef] 
73. Le, D.T.; Uram, J.N.; Wang, H.; Bartlett, B.R.; Kemberling, H.; Eyring, A.D.; Skora, A.D.; Luber, B.S.; Azad, N.S.; Laheru, D.; et al. PD-1 Blockade in Tumors with Mismatch-Repair Deficiency. N. Engl. J. Med. 2015, 372, 2509-2520. [CrossRef]

74. Polom, K.; Marano, L.; Marrelli, D.; De Luca, R.; Roviello, G.; Savelli, V.; Tan, P.; Roviello, F. Meta-analysis of microsatellite instability in relation to clinicopathological characteristics and overall survival in gastric cancer. Br. J. Surg. 2018, 105, 159-167. [CrossRef]

75. Kim, Y.; Cho, M.Y.; Kim, J.; Kim, S.N.; Oh, S.C.; Lee, K.A. Profiling cancer-associated genetic alterations and molecular classification of cancer in Korean gastric cancer patients. Oncotarget 2017, 8, 69888-69905. [CrossRef]

76. Polom, K.; Marrelli, D.; Pascale, V.; Ferrara, F.; Voglino, C.; Marini, M.; Roviello, F. The pattern of lymph node metastases in microsatellite unstable gastric cancer. Eur. J. Surg. Oncol. J. Eur. Soc. Surg. Oncol. Br. Assoc. Surg. Oncol. 2017, 43, 2341-2348. [CrossRef]

77. Kim, K.J.; Yang, H.K.; Kim, W.H.; Kang, G.H. Combined prognostic effect of PD-L1 expression and immunoscore in microsatellite-unstable advanced gastric cancers. Oncotarget 2017, 8, 58887-58902. [CrossRef]

78. Cho, J.; Lee, J.; Bang, H.; Kim, S.T.; Park, S.H.; An, J.Y.; Choi, M.G.; Lee, J.H.; Sohn, T.S.; Bae, J.M.; et al. Programmed cell death-ligand 1 expression predicts survival in patients with gastric carcinoma with microsatellite instability. Oncotarget 2017, 8, 13320-13328. [CrossRef]

79. Cunningham, D.; Allum, W.H.; Stenning, S.P.; Thompson, J.N.; Van de Velde, C.J.; Nicolson, M.; Scarffe, J.H.; Lofts, F.J.; Falk, S.J.; Iveson, T.J.; et al. Perioperative chemotherapy versus surgery alone for resectable gastroesophageal cancer. N. Engl. J. Med. 2006, 355, 11-20. [CrossRef] [PubMed]

80. Smyth, E.C.; Wotherspoon, A.; Peckitt, C.; Gonzalez, D.; Hulkki-Wilson, S.; Eltahir, Z.; Fassan, M.; Rugge, M.; Valeri, N.; Okines, A.; et al. Mismatch Repair Deficiency, Microsatellite Instability, and Survival: An Exploratory Analysis of the Medical Research Council Adjuvant Gastric Infusional Chemotherapy (MAGIC) Trial. JAMA Oncol. 2017, 3, 1197-1203. [CrossRef] [PubMed]

81. Choi, Y.Y.; Kim, H.; Shin, S.J.; Kim, H.Y.; Lee, J.; Yang, H.K.; Kim, W.H.; Kim, Y.W.; Kook, M.C.; Park, Y.K.; et al. Microsatellite Instability and Programmed Cell Death-Ligand 1 Expression in Stage II/III Gastric Cancer: Post Hoc Analysis of the CLASSIC Randomized Controlled study. Ann. Surg. 2019, 270, 309-316. [CrossRef]

82. Pietrantonio, F.; Miceli, R.; Raimondi, A.; Kim, Y.W.; Kang, W.K.; Langley, R.E.; Choi, Y.Y.; Kim, K.M.; Nankivell, M.G.; Morano, F.; et al. Individual Patient Data Meta-Analysis of the Value of Microsatellite Instability As a Biomarker in Gastric Cancer. J. Clin. Oncol. 2019, 37, 3392-3400. [CrossRef] [PubMed]

83. Sousa, H.; Pinto-Correia, A.L.; Medeiros, R.; Dinis-Ribeiro, M. Epstein-Barr virus is associated with gastric carcinoma: The question is what is the significance? World J. Gastroenterol. 2008, 14, 4347-4351. [CrossRef] [PubMed]

84. Cho, J.; Kang, M.S.; Kim, K.M. Epstein-Barr Virus-Associated Gastric Carcinoma and Specific Features of the Accompanying Immune Response. J. Gastric Cancer 2016, 16, 1-7. [CrossRef] [PubMed]

85. Van Beek, J.; zur Hausen, A.; Klein Kranenbarg, E.; van de Velde, C.J.; Middeldorp, J.M.; van den Brule, A.J.; Meijer, C.J.; Bloemena, E. EBV-positive gastric adenocarcinomas: A distinct clinicopathologic entity with a low frequency of lymph node involvement. J. Clin. Oncol. 2004, 22, 664-670. [CrossRef]

86. Camargo, M.C.; Murphy, G.; Koriyama, C.; Pfeiffer, R.M.; Kim, W.H.; Herrera-Goepfert, R.; Corvalan, A.H.; Carrascal, E.; Abdirad, A.; Anwar, M.; et al. Determinants of Epstein-Barr virus-positive gastric cancer: An international pooled analysis. Br. J. Cancer 2011, 105, 38-43. [CrossRef]

87. Ma, C.; Patel, K.; Singhi, A.D.; Ren, B.; Zhu, B.; Shaikh, F.; Sun, W. Programmed Death-Ligand 1 Expression Is Common in Gastric Cancer Associated With Epstein-Barr Virus or Microsatellite Instability. Am. J. Surg. Pathol. 2016, 40, 1496-1506. [CrossRef]

88. Derks, S.; Liao, X.; Chiaravalli, A.M.; Xu, X.; Camargo, M.C.; Solcia, E.; Sessa, F.; Fleitas, T.; Freeman, G.J.; Rodig, S.J.; et al. Abundant PD-L1 expression in Epstein-Barr Virus-infected gastric cancers. Oncotarget 2016, 7, 32925-32932. [CrossRef]

89. Kim, S.T.; Cristescu, R.; Bass, A.J.; Kim, K.M.; Odegaard, J.I.; Kim, K.; Liu, X.Q.; Sher, X.; Jung, H.; Lee, M.; et al. Comprehensive molecular characterization of clinical responses to PD-1 inhibition in metastatic gastric cancer. Nat. Med. 2018, 24, 1449-1458. [CrossRef] [PubMed]

90. Kapoor, N.; Bassi, A.; Sturgess, R.; Bodger, K. Predictive value of alarm features in a rapid access upper gastrointestinal cancer service. Gut 2005, 54, 40-45. [CrossRef] [PubMed] 
91. Fanotto, V.; Uccello, M.; Pecora, I.; Rimassa, L.; Leone, F.; Rosati, G.; Santini, D.; Giampieri, R.; Di Donato, S.; Tomasello, G.; et al. Outcomes of Advanced Gastric Cancer Patients Treated with at Least Three Lines of Systemic Chemotherapy. Oncologist 2017, 22, 1463-1469. [CrossRef]

92. Hess, L.M.; Michael, D.; Mytelka, D.S.; Beyrer, J.; Liepa, A.M.; Nicol, S. Chemotherapy treatment patterns, costs, and outcomes of patients with gastric cancer in the United States: A retrospective analysis of electronic medical record (EMR) and administrative claims data. Gastric Cancer 2016, 19, 607-615. [CrossRef]

93. Lin, S.J.; Gagnon-Bartsch, J.A.; Tan, I.B.; Earle, S.; Ruff, L.; Pettinger, K.; Ylstra, B.; van Grieken, N.; Rha, S.Y.; Chung, H.C.; et al. Signatures of tumour immunity distinguish Asian and non-Asian gastric adenocarcinomas. Gut 2015, 64, 1721-1731. [CrossRef]

94. Cherny, N.I.; Sullivan, R.; Dafni, U.; Kerst, J.M.; Sobrero, A.; Zielinski, C.; Piccart, M.J.; Bogaerts, J.; Tabernero, J.; Latino, N.J.; et al. ESMO-Magnitude of Clinical Benefit Scale V.1.0 questions and answers. ESMO Open 2016, 1, e000100. [CrossRef]

95. Cherny, N.I.; Vries, E.G.E.d.; Dafni, U.; Garrett-Mayer, E.; McKernin, S.E.; Piccart, M.; Latino, N.J.; Douillard, J.-Y.; Schnipper, L.E.; Somerfield, M.R.; et al. Comparative Assessment of Clinical Benefit Using the ESMO-Magnitude of Clinical Benefit Scale Version 1.1 and the ASCO Value Framework Net Health Benefit Score. J. Clin. Oncol. 2019, 37, 336-349. [CrossRef]

(C) 2020 by the authors. Licensee MDPI, Basel, Switzerland. This article is an open access article distributed under the terms and conditions of the Creative Commons Attribution (CC BY) license (http://creativecommons.org/licenses/by/4.0/). 